\title{
Genetics of Congenital Diaphragmatic Hernia
}

\author{
Gabriele Starker, Ismini Staboulidou, Cornelia Beck, \\ Konstantin Miller and Constantin von Kaisenberg \\ Hannover Medical School
}

Germany

\section{Introduction}

The frequency of congenital diaphragmatic hernia in live borns is 1:3000 (Langham et al., 1996). Congenital diaphragmatic hernia is a potentially life threatening condition and is associated with significant perinatal mortality and morbidity (Skari et al., 2000; Torfs et al., 1992).

The most important prognostic parameter is the presence / absence of chromosomal abnormalities (Table 1) and / or genetic syndromes (Table 2), although factors such as pulmonary lung hypoplasia, a liver displaced into the thorax and associated anomalies may be similarly important (Fig. 1).

This chapter deals with the genetics of $\mathrm{CDH}$ looking both at numerical and structural chromosomal abnormalities and the known mutations and genetic syndromes. This has important implications for the diagnostic workup during pregnancy and the subsequent management of the pregnancy and birth.

\section{Classification of congenital diaphragmatic hernia}

In about $80-85 \%$ of $\mathrm{CDH}$ the hernia is on the left side, in $10-15 \%$ on the right side and in $5 \%$ bilaterally (Dott et al., 2003). Most diaphragmatic defects involve the posterior and lateral aspects of the diaphragm, such as the posterolateral or Bochdalek CDH $(80-90 \%)$, often accompanied by herniation of the stomach, intestines, liver and spleen into the chest (Torfs et al., 1992). In cases of aplasia or agenesis of the diaphragm, CDH is summarized under the large Bochdalek defects (Baglaj et al., 1999). In about $5 \%$, the defect is in other locations affecting e.g. the anterior retrosternal or parasternal diaphragm, referred to as the Morgagni-Larrey hernia. In these cases, there can be hernation of liver or intestines into the chest cavity. Other anterior hernias are associated with Cantrell's Pentalogy including defects of the supraumbilical midline abdominal wall, the lower sternum, the diaphragmatic pericardium and there may be ectopia cordis. Central hernias affect the tendinous portion of the diaphragm.

\section{Etiology}

Etiological concepts include abnormalities of the retinoic pathways, the mesenchymal development and the dual hit hypothesis. 
The retinoic hypothesis: some of the loci such as 15q26, 8p23.1 and 8q23 are involved in the retinoic acid pathway and metabolism and are strongly association with $\mathrm{CDH}$ (Beurskens et al., 2010; Greer et al., 2003).

The mesenchymal-hit hypothesis: $\mathrm{CDH}$ originates from an abnormal development of the primordial pleuroperitoneal folds (PPF), important structures of the embryogenesis of the diaphragm. Genes affecting PPF development are COUP-TFII, FOG2, GATA-4, WT1 and Disp1, expressed in the non-muscular mesenchymal components of the diaphragm (Clugston et al., 2006; Clugston et al., 2008; Kantarci et al., 2010). Disp 1 is expressed in the primordial pleuroperitoneal fold (PPF), in diaphragmatic tissues and in the developing lung mesothelium, epithelium, and mesenchyme (Kantarci et al., 2010).

The dual-hit hypothesis: the lung is first hit by primary pulmonary underdevelopment through arrest of the alveolar development at the mid-canalicular stage, secondly the lung is hit by mechanical compression (Keijzer et al., 2000).

It has become increasingly evident that genetic factos play an important role in the etiology of $\mathrm{CDH}$. There is one known mutation in a single gene causing isolated CDH. For complex $\mathrm{CDH}$ several single gene mutation in various genes have been identified responsible for a specific syndrome. Alternatively, complex $\mathrm{CDH}$ may be associated with rearrangement in specific gene loci. However, it is still uncertain whether genetic factors are the sole cause of $\mathrm{CDH}$.

The evidence from teratogen and dietary-induced animal models is suggestive of differences in nutritional habits and other environmental factors contributing to a different susceptibility and phenotypical outcome (Beurskens et al., 2009).

\section{Prognostic factors}

The fate of the neonate will essentially be determined by an underlying systemic chromosomal or genetic abnormality on the one hand and by pulmonary hypoplasia or additional anatomical defects on the other hand. Anomalies may or may not be associated with chromosomal problems.

The total mortality in $\mathrm{CDH}$ is up to $50 \%$ and may be as little as $10-20 \%$ in isolated cases (Colvin et al., 2005; Skari et al., 2000; Stege et al., 2003). In the presence of associated anatomical defects as in complex $\mathrm{CDH}$, the mortality rate is increased (Cohen et al., 2002). Other factors are the size of the diaphragmatic defect (Lally et al., 2007), the side with rightsided $\mathrm{CDH}$ showing a higher mortality than those on the left, presumably because the liver is up, and bilateral CDH showing the highest mortality (Skari et al., 2000). Other prognostic determinants are if the liver ís up in the chest or below the diaphragm (Albanese et al., 1998), the degree of pulmonary hypoplasia and the development and degree of pulmonary hypertension in the perinatal period (reviewed in (Pober et al., 1993)).

\section{Isolated CDH}

An isolated $\mathrm{CDH}$ is a defect, which may be associated with additional anomalies, but these affect fetal hemodynamics or describe mechanical consequences of the $\mathrm{CDH}$. Those defects include dextroposition of the heart, a small compressed heart, tricuspid or mitral valve 
regurgitation, pulmonary hypoplasia, a patent foramen ovale or ductus arteriosus, malrotation or incomplete rotation of bowel, undescended testes and accessory spleen (Pober, 2008). The recurrence risk of isolated CDH in an sibling is 1-2\% (Czeizel \& Kovacs, 1985; Pober et al., 2005).

To date there is only one known de novo mutation in the FOG2 gene, which is the only single gene mutation causing isolated CDH (Ackerman et al., 2005).

\section{Complex CDH}

A complex $\mathrm{CDH}$ is a situation, where the $\mathrm{CDH}$ is associated with additional malformations. There may be associated chromosomal abnormalities, monogenetic syndromes or cases of complex CDH not part of a known genetic syndrome (Pober, 2008).

In about $60 \%, \mathrm{CDH}$ is isolated, in $40 \%$ complex $\mathrm{CDH}$ due to the presence of additional major malformations, chromosomal abnormalities or single gene disorders (Colvin et al., 2005; Dott et al., 2003; Skari et al., 2000; Torfs et al., 1992).

\subsection{CDH and chromosomal abnormalities}

The following paragraph specifies the most common numerical and structural abnormalities including deletions, duplications and translocations associated with $\mathrm{CDH}$. Since chromosomal abnormalities of nearly all chromosomes have been described in association with CDH we present "hot spots", which are likely to contain genes contributing to $\mathrm{CDH}$ and which are the best characterized to date. For a detailed list of chromosomal abnormalities we suggest excellent reviews which have been published (Holder et al., 2007; Lurie, 2003).

\subsubsection{Numerical chromosomal abnormalities}

Numerical chromosomal abnormalities are found in about $10 \%$ of $\mathrm{CDH}$.

Congenital diaphragmatic hernia is part of the common chromosomal abnormalities such as the trisomies $18(10 \%)$ and $13(6 \%)$ and in triploidy (2\%) (Table 1) (Snijders \& Nicolaides, 1996). It has also been described in Turner syndrome (Bohn, 2002). The frequency of chromosomal abnormalities in the total $\mathrm{CDH}$ group is $18 \%, 2 \%$ if the $\mathrm{CDH}$ is isolated and $34 \%$, if there are additional anomalies (Snijders \& Nicolaides, 1996).

In a series of 155 cases of Trisomy 21, there is nuchal edema (38\%), mild hydronephrosis (30\%), short femur (28\%), cardiac abnormalities (26\%), abnormal hands and feet $(25 \%)$, hydrops $(20 \%)$, small for gestational age (20\%), cerebral ventriculomegaly (16\%), brachycephaly $(15 \%)$, chorioid plexus cysts $(8 \%)$, duodenal atresia $(8 \%)$, enlarged cisterna magna $(7 \%)$, absent stomach $(3 \%)$, talipes (3\%) and no case of CDH (Snijders \& Nicolaides, 1996). In Trisomy 21, the frequency of $\mathrm{CDH}$ is low and of the Morgangi-type (Parmar et al., 2001).

In a series of 137 cases of Trisomy 18, there is intrauterine growth restriction (74\%), there are abnormal hands and feet (72\%), strawberry-shaped head (54\%), micrognathia (53\%), cardiac abnormalities $(52 \%)$, chorioid plexus cysts $(45 \%)$, exomphalos $(31 \%)$, talipes $(30 \%)$, brachycephaly $(29 \%)$, short femur $(25 \%)$, esophageal atresia or absent stomach $(20 \%)$, mild hydronephrosis $(16 \%)$, cerebral ventriculomegaly $(14 \%)$, other renal abnormalities $(12 \%)$, 
diaphragmatic hernia (10\%), posteria fossa cyst $(10 \%)$, facial cleft $(10 \%)$ (Benacerraf et al., 1988; Snijders \& Nicolaides, 1996; Tongsong et al., 2002).

In a series of 54 cases of Trisomy 13, there is intrauterine growth restriction (61\%), abnormal hands and feet (52\%), cardiac abnormalities (43\%), facial cleft and holoprosencephaly (39\%), mild hydronephrosis (37\%), brachycephaly (26\%), enlarged cisterna magna (25\%), microcephaly (24\%), other renal abnormalities (24\%), nuchal edema $(22 \%)$, exomphalos $(17 \%)$, posterior fossa cyst $(15 \%)$, talipes $(11 \%)$, short femur $(9 \%)$, cerebral ventriculomegaly $(9 \%)$, micrognathia (9\%), hydrops (7\%), diaphragmatic hernia (6\%) (Snijders \& Nicolaides, 1996).

\begin{tabular}{|c|c|c|c|c|c|}
\hline \multirow{3}{*}{ Fetal abnormality } & \multicolumn{5}{|c|}{ Chromosomal defect } \\
\hline & \multicolumn{3}{|c|}{ Trisomy } & \multirow{2}{*}{$\begin{array}{c}\text { Triploidy } \\
n=50\end{array}$} & \multirow{2}{*}{$\begin{array}{c}\text { Turner } \\
n=65\end{array}$} \\
\hline & $\begin{array}{c}21 \\
n=155\end{array}$ & $\begin{array}{c}18 \\
n=137\end{array}$ & $\begin{array}{c}13 \\
n=54\end{array}$ & & \\
\hline \multicolumn{6}{|l|}{ Skull/Brain } \\
\hline Strawberry shaped head & - & $54 \%$ & - & - & - \\
\hline Brachycephaly & $15 \%$ & $29 \%$ & $26 \%$ & $10 \%$ & $32 \%$ \\
\hline Microcephaly & - & $1 \%$ & $24 \%$ & - & $5 \%$ \\
\hline Ventriculomegaly & $16 \%$ & $14 \%$ & $9 \%$ & $18 \%$ & $2 \%$ \\
\hline Holoprosencephaly & - & $3 \%$ & $39 \%$ & - & - \\
\hline Choroid plexus cysts & $8 \%$ & $47 \%$ & $2 \%$ & - & - \\
\hline Absent corpus callosum & - & $7 \%$ & - & - & - \\
\hline Posterior fossa cyst & $1 \%$ & $10 \%$ & $15 \%$ & $6 \%$ & - \\
\hline Enlarged cisterna magna & $7 \%$ & $16 \%$ & $25 \%$ & - & - \\
\hline \multicolumn{6}{|l|}{ Face/Neck } \\
\hline Facial cleft & $1 \%$ & $10 \%$ & $39 \%$ & $2 \%$ & - \\
\hline Micrognathia & $1 \%$ & $53 \%$ & $9 \%$ & $44 \%$ & - \\
\hline Nuchal oedema & $38 \%$ & $5 \%$ & $22 \%$ & $4 \%$ & $6 \%$ \\
\hline Cystic hygromata & $1 \%$ & $2 \%$ & - & - & $88 \%$ \\
\hline \multicolumn{6}{|l|}{ Chest } \\
\hline Diaphragmatic hernia & - & $10 \%$ & $6 \%$ & $2 \%$ & - \\
\hline Cardiac abnormality & $26 \%$ & $52 \%$ & $43 \%$ & $16 \%$ & $48 \%$ \\
\hline \multicolumn{6}{|l|}{ Abdomen } \\
\hline Exomphalos & - & $31 \%$ & $17 \%$ & $2 \%$ & - \\
\hline Duodenal atresia & $8 \%$ & - & $2 \%$ & - & - \\
\hline Absent stomach & $3 \%$ & $20 \%$ & $2 \%$ & $2 \%$ & - \\
\hline Mild hydronephrosis & $30 \%$ & $16 \%$ & $37 \%$ & $4 \%$ & $8 \%$ \\
\hline Other renal abnormalities & $7 \%$ & $12 \%$ & $24 \%$ & $6 \%$ & $6 \%$ \\
\hline \multicolumn{6}{|l|}{ Other } \\
\hline Hydrops & $20 \%$ & $4 \%$ & $7 \%$ & $2 \%$ & $80 \%$ \\
\hline Small for gestational age & $20 \%$ & $74 \%$ & $61 \%$ & $100 \%$ & $55 \%$ \\
\hline Relatively short femur & $28 \%$ & $25 \%$ & $9 \%$ & $60 \%$ & $59 \%$ \\
\hline Abnormal hands / feet & $25 \%$ & $72 \%$ & $52 \%$ & $76 \%$ & $2 \%$ \\
\hline Talipes & $3 \%$ & $30 \%$ & $11 \%$ & $8 \%$ & - \\
\hline
\end{tabular}

Table 1. Incidence of ultrasound abnormalities in 461 fetuses with chromosomal defects that were examined at the Harris Birthright Research Centre for Fetal Medicine (Snijders \& Nicolaides, 1996). 
In a series of 65 cases of Turner syndrome, there was no case with diaphgragmatic hernia (Snijders \& Nicolaides, 1996).

In a series of 50 cases of Triploidy, the main features were intrauterine growth restriction $(100 \%)$, abnormal hands and feet $(76 \%)$, short femur $(60 \%)$, micrognathia $(44 \%)$ and diaphragmatic hernia (2\%) (Snijders \& Nicolaides, 1996).

\subsubsection{Supernumerary derivative chromosome 22 syndrome}

\section{+der(22)t(11;22)(q23;q11), Emanuel syndrome OMIM \#609029}

This syndrome is caused by a duplication of chromosomal segments of chromosomes 11 and 22 due to a 3:1 malsegregation of a common reciprocal translocation between the long arms of chromosome 11 and 22. In this partial duplication 11(q23-qter) and 22(pter-q11) complex $\mathrm{CDH}$ has been observed (Kadir et al., 1997). There is growth retardation, mental retardation, cardiovascular malformation, craniofacial anomalies (including preauricular tags or sinuses, micrognathia, ear anomalies, cleft or high-arched palate), microcephaly, kidney abnormalities and genital abnormalities in males (Carter et al., 2009).

\subsubsection{Structural chromosomal abnormalities}

In this section, we present examples for missing genes or genes with disturbed function caused by deletions or micro-deletions or by abnormal structure formation of chromosomes, clinically resulting in $\mathrm{CDH}$.

\section{Deletions}

$$
\operatorname{del}(1)(q 41-q 42.12) \text { OMIM \#612530 }
$$

This abnormality affects the DISP 1 gene (Kantarci et al., 2010; Shaffer et al., 2007). The clinical features are $\mathrm{CDH}$ and holoprosencephaly. There is a clinical overlap with the Fryns syndrome (Kantarci et al., 2006).

\section{del(4)(p16) Wolf-Hirschhorn syndrome (WHS) OMIM \#194190}

This abnormality affects 4p16.3. The clinical features include pre- and postnatal growth deficiency, developmental disability of variable degree, characteristic craniofacial features ('greek warrior helmet' appearance of the high-arched eyebrows and the nose, high forehead, prominent glabella, hypertelorism, protruding eyes, epicanthal folds, short philtrum, distinct mouth with downturned corners, and micrognathia), seizures, closure defects (cleft lip or palate, coloboma of the eye) and cardiac septal defects. Diaphragmatic hernia is a rare feature of the WHS phenotype (Casaccia et al., 2006; Sergi et al., 1998).

\section{$\operatorname{del}(8)($ 23.1) OMIM \#222400}

This deletion removes GATA-4, a gene which is important for the development of the diaphragm and the heart and lung (Ackerman et al., 2007). Clinical features include cardiovascular malformations, intellectual disability, mild facial dysmorphology, renal anomalies and $\mathrm{CDH}$ in up to $20 \%$.

\section{$\operatorname{del}(8)(q 23.1)$ OMIM \#610187}

This deletion removes the ZFPM2 (FOG 2) gene. The clinical result is isolated CDH and pulmonary hypoplasia (Ackerman et al., 2005; Bleyl et al., 2007). 


\section{del(15)(q26.1-q26.2) OMIM \#142340}

There may be a de novo deletion of terminal $15 \mathrm{q}$ or a loss of chromosomal material caused by unbalanced translocations or ring chromosome 15 formation (Pober et al., 2005). The 15q26.1-q26.2 deletion may result in removal of COUP-TFII, CDH2, RGMA, SIAT8B and MEF2A (Biggio et al., 2004; Klaassens et al., 2005). Epigenetic factors likely contribute to the development of $\mathrm{CDH}$ for this gene. The clinical phenotype is intrauterine growth retardation, intellectual disability, facial dysmorphology, limb, renal and cardiovascular malformations, hypoplastic genitalia and CDH. There is a high mortality of $30-60 \%$ in newborns (Klaassens et al., 2007; Langham et al., 1996).

\section{Isochromosome}

\section{Isochromosome 12p (Tetrasomy 12p) Pallister-Killian syndrome (PKS) OMIM \#601803}

This syndrome is characerized by the mosaic presence of a supernumerary isochromosome of the short arm of chromosome 12 in some tissues. This results in 4 copies of the genes on chromosome 12p (Struthers et al., 1999). The clinical features include (prenatally): short limbs, CNS anomalies, cerebral ventricular dilatation, craniofacial dysmorphology, excess fluid accumulation such as nuchal edema/hydrops fetalis, polyhydramnion and CDH in 10$50 \%$ (Doray et al., 2002; Mowery-Rushton et al., 1997). In addition postnatally there is bitemporal sparseness of hair, facial dysmorphology (brachycephaly, high broad forehead, ocular hypertelorism, low-set ears, broad nasal bridge, anteverted nostrils, long philtrum), short neck with nuchal skin redundancy, short broad hands, syndactyly, linear streaks of skin hyperpigmentation, normal growth, seizures and moderate intellectual disability.

There is some clinical overlap with Fryns Syndrome. A large number of fetuses are stillborn or die in the neonatal period.

Tetrasomy 12 mosaicism can be diagnosed from skin fibroblasts, chorionic villi and amniotic fluid cells, whereas in lymphocytes from cordocentesis, the isochromosome is likely to be missed (Doray et al., 2002).

\subsection{Monogenic syndromes with $\mathrm{CDH}$ as common symptom}

There are more than 70 syndromes in which diaphragmatic hernia has been observed (Slavotinek, 2007). This paragraph deals with selected syndromes most commonly associated with $\mathrm{CDH}$. For further syndromes in which $\mathrm{CDH}$ has been described only in a few cases see Online Mendelian Inheritance In Man (OMIM) of John Hopkins University.

Defects on almost all chromosomes have been described in patients with $\mathrm{CDH}$ which considerably complicates the unravelling of the etiology of CDH (Holder et al., 2007). The genetic heterogeneity might reflect interactions of several candidate genes at the protein level. Certain proteins function at different steps of a pathway and errors may therefore occur at many levels, causing different specific disease phenotypes (Klaassens et al., 2009).

\section{Cornelia de Lange syndrome 1 (CDLS1) OMIM \#122470}

CDLS is in about $50-60 \%$ a de novo autosomal dominant mutation in the NIPBL gene on 5p13.1. (Gillis et al., 2004), there are also in about 5\% X-linked mutations in the SMC1A gene on Xp11.2, a mild variant of CDLS is caused by a mutation in the SMC3 gene on 10q25.2. 
The prevalence is 0.6-10:100.000 individuals.

Clinical features include (prenatally): intrauterine growth restriction, hypoplastic forearms, underdevelopment of the hands, typical facial defects and diaphragmatic hernia (Manouvrier et al., 1996). Postnatally, growth retardation, hirsutism, mental retardation, microcephaly, upper limb reduction defects such as oligodactyly, dysmorphic facial appearance (low anterior hairline, synophrys, arched eyebrowns, long eyelashes, small upturned nose with a long philtrum, thin upper lip, downturned corners of the mouth, small widely spaced teeth) are found (Gillis et al., 2004), in 5-10\% with CDH (Martinez-Frias et al., 1998). There is reduced survival. The phenotype is highly variable. The empiric risk for a sib of an affected child is between 2 and $5 \%$.

Prenatal molecular genetic testing is available.

\section{Craniofrontonasal syndrome (CFNS) OMIM \#304110}

CFNS is a mutations in the EFNB1 gene on Xq12 (Wieland et al., 2004). Craniofrontonasal syndrome is an X-linked developmental disorder that shows paradoxically greater severity in heterozygous females than in hemizygous males. A possible explanation could be, that EFNB1 escapes $X$ inactivation. There is some overlap with Hypertelorism of the Teebi Type (OMIM \#145420) which includes CDH.

The prevalence is unknown.

Clinical features include in Females: coronal craniosynostosis, craniofacial dysmorphism: hypertelorism, broad nasal bridge, broad nasal tip, facial asymmetry, frontal bossing, widow's peak, curly hair, cleft lip and palate, a variety of skeletal abnormalities such as grooved nails and $\mathrm{CDH}$.

Clinical features include in Males: hypertelorism or telecanthus, short stature, potentially mild musculoskeletal abnormalities (Saavedra et al., 1996; Vasudevan et al., 2006).

Prenatal molecular genetic testing is available.

\section{Donnai-Barrow syndrome (facio-oculo-acoustico-renal syndrome) OMIM \#222448}

This is a mutation in the LPR2 gene on $2 \mathrm{q} 23.3-2 \mathrm{q} 31.1$, inheritance is autosomal recessive (Chassaing et al., 2003; Gripp et al., 1997; Kantarci et al., 2007).

The prevalence is unknown.

Clinical features include high myopia, coloboma, hypertelorism, complete or partial agenesis of the corpus callosum, sensorineural hearing loss, cardiac defects, facial dysmorphology (wide anterior fontanelle, downslanting palpebral fissures, epicanthal folds, short nose with a broad tip, low-set posteriorly angulated ears), developmental delay, low-molecular-weight proteinuria, omphalocele and in about 50\% CDH (Donnai \& Barrow, 1993).

Prenatal molecular genetic testing at present is available only for research.

\section{Fryns syndrome OMIM \#229850}

The clinical phenotype of Fryns syndrome has been observed in association with mosaicism for a tandem duplication of 1q24-q31.2 (Clark \& Fenner-Gonzales, 1989), but also in association with anomalies of chromosome 6, 15 and 22 respectively (de Jong et al., 1989; Dean et al., 1991; 
Krassikoff \& Sekhon, 1990) indicating genetic heterogeneity of the syndrome. Thus, these cases may all represent mimics of the mendelian syndrome and have no significance as to the location of the gene for the recessive disorder. The gene responsible for Fryns syndrome is not yet known. There is an autosomal recessive Fryns (OMIM \#229850), there is a type with chromosomal microdeletion and microduplication phenocopies and there are autosomal recessive phenocopies due to mutations in other genes (Pober, 2008).

The prevalence is 7:100.000 live births (Ayme et al., 1989).

A common finding in complex $\mathrm{CDH}$, in about 10\%, is Fryns syndrome (Slavotinek, 2004), therefore it is the most likely diagnosis in the clinical finding of $\mathrm{CDH}$ with associated anomalies (Fryns et al., 1979; Neville et al., 2002).

Guidelines for classifying Fryns syndrome using 5 categories (Lin et al., 2005):

- $\mathrm{CDH}$ : approximately $80 \%$ have a congenital abnormality of the diaphragm, most commonly Bochdalek's hernia.

- pulmonary hypoplasia: always accompanies $\mathrm{CDH}$.

- facial dysmorphology: coarsened face, flattened nasal bridge, thickened nasal tip, long philtrum, hypertelorism, non-specific ear anomalies, widely spaced eyes, macrostomia, micrognathia.

- distal digital hypoplasia: small nails and/or distal phalanges.

- characteristic pattern of additional anomalies: mainly cardiovascular, renal and brain malformations, at least one of: polyhydramnios, cloudy cornea and/or microphthalmia, orofacial cleft, brain malformation, cardiovascular malformation, renal dysplasia and cortical renal cysts, gastrointestinal malformations, genital malformations.

- $\quad$ similarly affected sibling.

A classical definition of Fryns syndrome includes four of the six clinical findings, a more widely definition three out of six features.

Key ultrasound features include polyhydramnios in half of the cases, $\mathrm{CDH}$ and cystic hygroma (Manouvrier-Hanu et al., 1996). The prognosis is poor as there are only about $15 \%$ survivors in the neonatal period and severe mental retardation is common in survivors (Slavotinek, 2004).

Matthew-Wood syndrome (PDAC or PMD syndrome) OMIM \#601186

This syndrome is caused by mutations in STRA6 on 15q24.1, a membrane receptor for vitamin A retinol binding protein and is autosomally recessive inherited (Pasutto et al., 2007).

Only a few cases have been reported so far, therefore the prevalence cannot be estimated to date.

Clinical features include microphthalmia or anophthalmia, pulmonary hypoplasia or agenesis, cardiac defects and CDH in up tp 50\% (Chitayat et al., 2007). The prognosis is poor as there is early lethality in most cases.

Prenatal molecular genetic testing at present is available only for research.

Spondylocostal dysostosis 1 SCD1 (Jarcho-Levin syndrome) OMIM \#277300

This syndrome is most frequently caused by a mutation in DLL3 on 19q13 and is autosomally recessive inherited. There are further autosomally recessive types of spondylocostal dysostosis 
(SCD2-4) and the respective gene mutations are: MESP2 on 15q26.1 (without CDH) OMIM \#608681, LFNG on 7p22.4 (without CDH) OMIM \#609813, HES7 on 17p13.1 (without CDH) OMIM \#613686 and SCD 5, autosomally dominant, OMIM \#122600.

The prevalence is unknown.

Clinical featues include multiple contiguous vertebral abnormalities, malalignment of the ribs with variable points of intercostal fusion, and often a reduction in rib number, shortened trunk, short neck, hemivertebrae, vertebral fusion, scoliosis, severe expression with respiratory compromise and death resulting from a significant reduction in chest size, cleft palate, renal anomalies, patent ductus arteriosus and CDH (Day \& Fryer, 2003; Rodriguez et al., 2004).

Spondylothoracic dysplasia (STD) OMIM \#277300

This syndrome shares phenotypic similarities with spondylocostal dysostosis. Main features are a "fan-like" configuration of the chest in which the ribs appear to emanate from only a few vertebral bodies, additional cardinal abnormalities include malformed vertebrae and ribs, genitourinary abnormalities and hernias and CDH (Day \& Fryer, 2003; Shehata et al., 2000).

Molecular genetic testing is available for DLL3, MESP2, LFNG (HES7 research only).

\section{Simon-Golabi-Behmel syndrome type 1 OMIM \#312870}

This is a syndrome caused by a mutation in the GPC3 gene on Xp26.2 (Pilia et al., 1996). It is $\mathrm{X}$-linked recessive inherited.

The prevalence is unknown.

Clinical features include prenatal or postnatal overgrowth, coarse facial features with hypertelorism, macrosomia, abdominal wall defects (including umbilical hernia and omphalocele), skeletal anomalies (including brachydactyly, postaxial polydactyly, cutaneous syndactyly), renal anomalies (hydronephrosis, cystic dysplatic kidney), supernumerary nipples, (Neri et al., 1998; Sakazume et al., 2007), an increased risk of embryonal tumors such as Wilms tumor and hepatocellular carcinoma (Li et al., 2001). The overgrowth is present from the prenatal period accompanied by macroglossia, an advanced bone age, organomegaly and neonatal hypoglycaemia (Neri et al., 1998). Structural and conductive cardiac abnormalities are seen in 35\%, there is also congenital hypotonia, seizures, brain malformations and developmental disability. The prognosis is poor as approximately $50 \%$ die in the neonatal period, survivors have low-normal intelligence.

Molecular genetic testing is available.

\section{WT1-opathies}

\section{Denys-Drash syndrome OMIM \#194080, Frasier syndrome OMIM \#136680, Meacham syndrome OMIM \#608978 and WAGR syndrome OMIM \#194072}

This group of genetic syndromes is caused by a mutation in WT1 on 11p13 and is autosomal dominant.

The WT1 gene is expressed in the septum transversum of the diaphragm and in the pleural and abdominal mesothelial tissue that form the diaphragm (Moore et al., 1998). Pathological 
studies have demonstrated defects in the formation of the primordial pleuroperitoneal folds (PPF) in WT1 null mice (Clugston et al., 2006).

It is likely that heterozygous mutations/deletions of WT1 increase the likelihood that an individual will develop CDH. Environmental factors and differences in genetic background may also play a role in determining whether an individual with a WT1 abnormality develops CDH (Scott et al., 2005). Although WT1 may play an important role in diaphragm development, abnormalities in WT1 do not appear to be a common cause of isolated diaphragmatic hernia.

Common features are $\mathrm{CDH}$ (not 100\%), genital abnormalities and associated anomalies (Antonius et al., 2008; Cho et al., 2006; Devriendt et al., 1995; Killeen et al., 2002; Scott et al., 2005; Suri et al., 2007).

The prevalence of these rare diseases are unknown.

Denys-Drash syndrome OMIM \#194080 triad consisting of nephropathy, Wilms tumor, and genital abnormalities (male pseudohermaphroditism) (Cho et al., 2006; Devriendt et al., 1995). Death is usually due to renal failure by average age 3 , most cases are sporadic.

Frasier syndrome OMIM \#136680 46,XY males with normal female external genitalia, hypospadias, cryptorchidism, streak gonads, progressive nephrotic syndrome with proteinuria secondary to focal and segmental glomerular sclerosis and gonadoblastoma (Denamur et al., 2000).

Meacham syndrome OMIM \#608978 complex cardiovascular malformations, lung defects including severe pulmonary hypoplasia, congenital bronchiectasis, pulmonary sequestration, ambigouous external genitalia or undervirilized male external genitalia with duplication of the vagina in chromosomal males (Meacham et al., 1991; Suri et al., 2007).

WAGR syndrome OMIM \#194072 Wilms tumor (50\%), aniridia, genitourinary anomalies, mental retardation, CDH is rare, genes are WT1 and PAX6 (Scott et al., 2005).

Molecular genetic testing is available.

\subsection{Selected syndromes with $\mathrm{CDH}$ as an occasional finding}

\section{Apert syndrome OMIM \#101200}

This syndrome is caused be a mutation in the FGFR2 gene on 10q26.13, autosomally dominant.

The estimated frequency of Apert syndrome is 1 in 160.000 births.

Clinical features include craniosynostosis, mid-face hypoplasia, ocular hypertelorism, fusion of cervical vertebrae, varying degree of bilateral soft tissue and bony syndactyly of hands and feet and developmental delay/intellectual disability in approximately 50\% (Pober et al., 1993).

Molecular genetic testing is available.

\section{Beckwith-Wiedemann syndrome OMIM \#130650}

This syndrome is caused by dysregulation of imprinted genes within the chromosome 11p15.5 region including CDKN1C, H19, and LIT1. Mutations in the NSD1 gene on 
chromosome $5 \mathrm{q} 35$ have been identified in two cases. It can be transmitted autosomal dominant while the majority of cases are a single occurrence in the family.

The population incidence is estimated to be 1:13.700 births. This figure is likely an underestimate as milder phenotypes may not be ascertained. The incidence is equal in males and females with the notable exception of monozygotic twins that show a dramatic excess of females (Weksberg et al., 2010).

Clinical features are overgrowth during the latter half of pregnancy and in the first few years of life while adult heights are generally in the normal range. Fetal adrenocortical cytomegaly is a pathognomonic finding during prenatal ultrasound examination. Additional features involve abdominal wall defects, earlobe creases or pits behind the upper ear, macroglossia and visceromegaly involving liver, spleen, pancreas, kidneys, or adrenals. Renal anomalies may include primary malformations, renal medullary dysplasia, nephrocalcinosis, and nephrolithiasis. Hypoglycemia is reported in 30 to $50 \%$ of babies and there is a predisposition to embryonal malignancies, with Wilms tumor and hepatoblastoma being the most common. $\mathrm{CDH}$ is a rare phenotypic finding (Pober et al., 1993; Turleau et al., 1984; Weksberg et al., 2010).

Molecular genetic testing is available.

\section{CHARGE syndrome OMIM \#214800}

Most cases result from de novo mutation in the CHD7 gene on 8q12.1 or in the SEMA3E gene on 7q21.11. The inheritance is autosomal dominant.

The incidence is 1:12.000 births.

The syndrome presents clinically with coloboma of the eye, cardiovascular malformations, choanal atresia or stenosis, growth and mental retardation, genital anomalies, ear anomalies, hearing loss and microcephaly (Casaccia et al., 2008; Vissers et al., 2004).

Molecular genetic testing is available.

\section{Trigonocephaly OMIM \#211750}

This syndrome is caused by a mutation in the CD96 gene on 3q13.1-q13.2. The inheritance is autosomal recessive.

The estimated incidence is 1:12.000 births.

The clinical presentation includes metopic craniosynostosis, orofacial anomalies (deep midline palatal groove, broad alveolar ridges, and multiple frenula), genital anomalies, cardiovascular defects, short limbs, polydactyly, loose skin and intellectual disability (Addor et al., 1995)

Molecular genetic testing is not available.

\section{Coffin-Siris syndrome OMIM \#135900}

This syndrome is caused by a mutation in the 7q32-q34 region. The specific gene and the inheritance are not yet known as the majority of cases are sporadic. Affected sibs have been described. Only about 40 cases are published and the prevalence is estimated to be less than 1:1.000.000. The most likely mode of inheritance is autosomal recessive and the recurrence risk is $25 \%$ for sibs of an index case. 
Clinical features are hypoplasia or absence of nail/phalanx of the fifth digit, scalp hypotrichosis, body hypertrichosis, facial dysmorphology (coarse face, wide mouth, full lips), growth retardation and intellectual disability. The female to male ratio is about 4:1 (Coffin \& Siris, 1970; Haspeslagh et al., 1984).

Molecular testing is not available.

\section{Cutis laxa, autosomal recessive type I OMIM \#219100}

This syndrome is caused by homozygosity for a missense mutation in the EFEMP2 gene, also known as FBLN4, on 11q13.1. There has also been described a mutation in the FBLN5 gene on $14 \mathrm{q} 32.12$ but this mutations has not been associated with $\mathrm{CDH}$.

The prevalence of this syndrome has been estimated about 1-9:1.000.000.

The main clinical feature is soft, velvety, and transparent skin. Additional observations include hypotonia, emphysema, generalized arterial tortuosity, joint laxity, pectus excavatum and inguinal and diaphragmatic hernia (Hoyer et al., 2009; Hucthagowder et al., 2006). Oligohydramnios is a typical finding of prenatal ultrasound examination.

Molecular genetic testing is available.

\section{Czeizel-Losonci syndrome OMIM \#183802}

The genetic cause of this syndrome is not yet known. It is autosomally dominant inherited. Molecular testing is not available. The incidence is not yet known as there are only a few cases described to date.

Clinical features are limb anomalies such as split hands/split feet, preaxial deficiency, and syndactyly, urinary tract obstruction, neural tube defects such as spina bifida and CDH (Czeizel \& Losonci, 1987).

\section{Ehlers Danlos syndrome type 1 OMIM \#130000}

This syndrome can be caused by a mutation in the collagen alpha-1(V) gene (COL5A1) on chromosome $9 \mathrm{q} 34$ or the collagen alpha-2(V) gene (COL5A2) on chromosome 2q31. One patient with EDS I has been reported to have a mutation in the collagen alpha-1(I) gene (COL1A1) on chromosome 17q. The inheritance is autosomal dominant.

Ehlers-Danlos syndrome (EDS) affects approximately 1:5.000 live births.

The main features of classic Ehlers-Danlos syndrome (EDS I and EDS II) are loosejointedness and fragile, bruisable skin that heals with peculiar 'cigarette-paper' scars (Beighton et al., 1998; Zalis \& Roberts, 1967). CDH is a rare feature.

Molecular genetic testing is available

\section{Gershoni-Baruch syndrome OMIM 609545}

The genetic cause of this syndrome is not yet known. It is autosomally recessive inherited (Franceschini et al., 2003). Molecular testing is not available. The incidence is not yet known as there are only a few cases described to date.

Clinical features include omphalocele, cardiovascular malformations, absent radial ray, vertebral anomalies, neural tube defect and a single umbilical artery (Gershoni-Baruch et al., 
1990). The perinatal lethality is very high. The clinical presentation of this syndrome overlaps with the DK phocomelia syndrome OMIM \#223340 which also includes CDH.

\section{Goltz syndrome (focal dermal hypoplasia) OMIM \#305600}

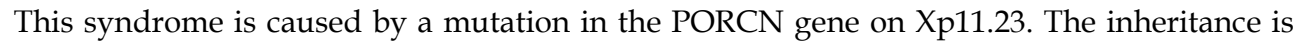
X-linked dominant with a high in utero lethality in males. The majority of cases $(95 \%)$ are sporadic. Ninety percent of cases are female. The frequency in a general population has not been estimated.

Goltz syndrome presents clinically with an asymmetric face, trunk and extremities, skin atrophy, subcutaneous nodules secondary of fat herniations through atrophic areas, alternating areas of hyper- and hypopigmentation, multiple mucous and perioral papilloma, oral anomalies including hypoplasia or aplasia of the teeth, enamel defects and malocclusion, ocular anomalies such as coloboma, microphthalmia and iris defects, osteopathia striata, skeletal abnormalities involving the extremities, short stature and mild mental deficiency. $\mathrm{CDH}$ is a rare feature (Han et al., 2000).

Molecular genetic testing is available

\section{Hemifacial microsomia (Goldenhar syndrome) OMIM \#164210}

This syndrome is caused by mutation in the $14 \mathrm{q} 32$ region. Most cases are sporadic, but there are rare familial cases that exhibit autosomal dominant inheritance.(Pober et al., 1993; Rollnick \& Kaye, 1983). Molecular testing is not available.

The estimated frequence is 1:3000-5000.

The malformations are caused by an abnormal morphogenesis of the first and second branchial arches and are often presented unilateral. Clinical features are facial asymmetry and ear anomalies. In addition to craniofacial anomalies, there may be cardiac, vertebral, and central nervous system defects (Pober et al., 1993). There is a slight male predominance (3:2).

\section{Kabuki syndrome OMIM \#147920}

This syndrome is caused by mutation in the MLL2 gene on 12q12-q14, autosomally dominant inherited.

Kabuki syndrome is estimated to occur in at least 1:32.000 Japanese individuals.

Kabuki syndrome is a congenital mental retardation syndrome with additional features, including postnatal dwarfism, a peculiar facies characterized by long palpebral fissures with eversion of the lateral third of the lower eyelids, a broad and depressed nasal tip, large prominent earlobes, a cleft or high-arched palate, scoliosis, short fifth finger, persistence of fingerpads, radiographic abnormalities of the vertebrae, hands, and hip joints, and recurrent otitis media in infancy as well as cardiovascular malformations (Donadio et al., 2000; Genevieve et al., 2004; Niikawa et al., 1981)

Molecular genetic testing is available

\section{Marfan syndrome OMIM \#154700}

This syndrome is caused by mutation in the FBN1 gene on 15q21.1 and is inherited autosomally dominant. However, about $25 \%$ of cases are due to new mutations. 
The estimated prevalence of Marfan syndrome is between 1:5.000-10.000.

Marfan syndrome is caused by connective tissue dysplasia characterized by tall statue, disproportionately long extremities, subluxation of the lens, myopia, dilatation of the descending aorta, variety of other anomalies such as pectus deformities, kyphoscoliosis, joint hypermobility and dural ectasia, diaphragmatic abnormalities are rare (Revencu et al., 2004).

Molecular genetic testing is available

Mathieu syndrome there is no OMIM entry

The genetic cause of this syndrome has not been identified yet and therefore there is no molecular genetic testing available. Autosomal dominant inheritance is assumed.

The prevalence has not been described as there are only a few cases known.

Clinical features include facial dysmorphology such as epicanthal folds, short nose, depressed nasal bridge and micrognathia, cleft palate, short statue, short neck, vertebral abnormalities, tracheal abomalies and mild intellectual disability (Mathieu et al., 1993; Zelante \& Ruscitto, 2003).

Microphthalmia with linear skin defect (MLS), MIDAS (MIcrophthalmia, Dermal Aplasia, Sclerocornea) syndrome OMIM \#309801

This syndrome is caused by mutation in the HCCS gene on Xp22.2. There is X-linked dominant inheritance with in utero lethality for males.

It has been reported in less than 50 patients and the prevalence is estimated $<1: 1.000 .000$.

The main clinical features in affected females are unilateral or bilateral microphthalmia and linear skin defects which are limited to the face and neck, consisting of areas of aplastic skin that heal with age to form hyperpigmented areas. Additional findings include sclerocornea, occasional cardiovascular malformations and genital anomalies (Wimplinger et al., 2006).

Molecular genetic testing is available.

\section{Multiple pterygium syndrome, Escobar variant (non-lethal type) OMIM \#265000}

This syndrome is caused by a mutation in the CHRNG gene on 2q37.1. The inheritance is autosomal recessive (Entezami et al., 1998; Morgan et al., 2006). The prevalence of this syndrome has not been described.

Multiple pterygium syndromes comprise a group of multiple congenital anomaly disorders characterized by webbing (pterygia) of the neck, elbows, and/or knees and joint contractures (arthrogryposis). Other features can be skeletal defects and genital anomalies (Morgan et al., 2006).

Molecular genetic testing is available.

\section{Myotubular myopathy 1 (MTM1) OMIM \#310400}

This syndrome is caused by a mutation in the MTM1 gene on Xq28. The inheritance is Xlinked recessive (Laporte et al., 1996). 
The incidence is estimated to be 1:50.000 newborn males.

This syndrome affects the skeletal muscle causing generalized muscle weakness. Other findings include it is congenital eventration of the diaphragm accompanied by diaphragmatic dysfunction causing serious respiratory problems (Grogan et al., 2005; Moerman et al., 1987). Therefore this syndrome is usually fatal in infancy. Some carrier females may manifest mild symptoms.

Molecular genetic testing is available.

\section{Opitz GBBB syndrome type 1 OMIM \#300000}

This syndrome is caused by mutation in the MID1 gene on $\mathrm{Xp} 22.2$. The inheritance has been described as X-linked.

The prevalence has been estimated to be 1-9:100.000.

Clinical features include hypertelorism, hypospadias, cleft lip/palate, laryngotracheoesophageal abnormalities, imperforate anus, developmental delay, and cardiac defects. CDH is a rare feature (Enns et al., 1998).

Molecular genetic testing is available.

\section{PAGOD syndrome OMIM 202660}

The gene mutation causing this syndrome is not known but it has been hypothized to cause a defect on the vitamin A pathway.

Only about 6 cases have been described thus the prevalence and inheritance cannot be predicted.

Diagnostic criteria are pulmonary hypoplasia, cardiovascular malformations including hypoplasia of the pulmonary artery, hypo- or agonadism, ambiguous genitalia, omphalocele, dextrocardia and CDH (Kennerknecht et al., 1993).

Molecular testing is not available.

Pentalogy of Cantrell OMIM \#313850 (included in THAS)

This extremely rare syndrome occurs sporadic and the genetic background has not been identified yet.

An evaluation of the prevalence of the pentalogy of Cantrell in the general population provided an estimate of 5.5:1.000.000 live births.

Diagnostic criteria are deficiency of anterior diaphragm, defect of the diaphragmatic pericardium, ectopia cordis or other cardiovascular malformations, supraumbilical abdominal wall defect and defect of lower sternum (Ghidini et al., 1988; Toyama, 1972). By definition, $\mathrm{CDH}$ is a part of this syndrome, but patients with incomplete pentalogy of Cantrell and without diaphragmatic hernias have been described (Song \& McLeary, 2000). The survival is severely compromised because of the cardiac defects (Bittmann et al., 2004).

Molecular testing is not available. 


\section{Perlman syndrome OMIM \#267000}

The gene causing this syndrome is not known but autosomal recessive inheritance is suggested.

So far, about 30 patients have been reported in the literature, therefore the prevalence cannot be predicted yet.

Prenatal findings in ultrasound examination include fetal ascites without hydrops and polyhydramnios. Clinical manifestations are macrosomia, nephromegaly with renal hamartomas and most often nephroblastomatosis, hepatomegaly, hyperplasia of the endocrine pancreas accompanied by hyperinsulinism, typical facial appearance, and an increased risk for Wilms tumor. There is a high neonatal lethality with intellectual disability in survivors (Greenberg et al., 1988; Perlman, 1986).

Molecular testing is not available.

\section{Poland syndrome OMIM \#173800}

This syndrome occurs sporadic and the genetic background has not been identified yet.

The prevalence at birth is about 1-3:100.000.

The clinical picture consists of unilateral absence or hypoplasia of the pectoralis muscle, most frequently involving the sternocostal portion of the pectoralis major muscle, and a variable degree of ipsilateral hand and digit anomalies, including symbrachydactyly (Hou \& Wang, 1999; McGillivray \& Lowry, 1977) .

Molecular testing is not available.

\section{Swyer syndrome 46,XY sex reversal 1 OMIM \#400044}

About $30 \%$ of cases affected by this syndrome are caused by mutation or deletion of SRY on Yp11.31. The disorder is caused not only by mutations in the SRY gene, but by genes on the autosome and the $\mathrm{X}$ chromosome. There has been found no SRY mutations in persons with Swyer syndrome and $\mathrm{CDH}$.

The prevalence is unknown.

Affected patients have a partial or complete gonadal dysgenesis. Individuals with $46, X Y$ complete gonadal dysgenesis are phenotypically female; however, they do not develop secondary sexual characteristics at puberty and do not menstruate. They have bilateral 'streak gonads,' which typically consist of fibrous tissue and variable amounts of wavy ovarian stroma. A uterus and fallopian tube are present and external genitalia are female (Berkovitz et al., 1991; Kent et al., 2004).

Molecular genetic testing is available

\section{Thoracoabdominal syndrome (THAS) OMIM \#313850}

This syndrome is caused by mutations in the Xq25-q26.1 region, the affected gene is unknown. The inheritance is presumably $X$-linked dominant.

The prevalence is estimated to be 1-9: 1.000.000. 
Clinical features include adominal wall defects such as absent or hypoplastic abdominis rectus muscle, diaphragm defects, hypoplastic lung, occasional cardiovascular malformations and cleft palate (Carmi et al., 1990). This syndrome includes the malformations of the Pentalogy of Cantrell syndrome.

Molecular testing is not available.

\section{4 $\mathrm{CDH}$ and other congenital malformations not part of a known genetic syndrome}

In this section, we describe cases of $\mathrm{CDH}$ associated with additional anomalies, which do not constitute a specific genetic syndrome. The most common associated defects are cardiovascular, central nervous and of the musculoskeletal system.

CDH and cardiovascular malformations: these are found in about $10-15 \%$ of nonsyndromic CDH cases (Dillon et al., 2000; Lin et al., 2007; Robert et al., 1997). A ventricular septal defect (VSD) or atrial septal defect (ASD) is the most frequent cardiac defect.

CDH and central nervous system abnormalities: they are found in about $5-10 \%$ of the nonsyndromic $\mathrm{CDH}$ cases, particularly neural tube defects and hydrocephalus are common (Dillon et al., 2000; Dott et al., 2003).

CDH and limb abnormalities: in $10 \%$ of the non-syndromic CDH cases, syndactyly, polydactyly or limb reduction defects are found (Colvin et al., 2005; Stege et al., 2003; van Dooren et al., 2003).

CDH and genitourinary abnormalities: undescended testes commonly coexist with $\mathrm{CDH}$, rarer findings are ectopic or absent testes and ectopic (thoracic) kidney. (Masturzo et al., 2001; Panda et al., 2009; van Dooren et al., 2003)

CDH and eye abnormalities: microphthalmia and anophthalmia are reported in several syndromes listed above (Macayran et al., 2002; Steiner et al., 2002).

\section{5 $\mathrm{CDH}$ in multiple gestation}

There is only little known about $\mathrm{CDH}$ in multigestational pregnancies. Of all cases with $\mathrm{CDH}$ about 3\% occur in multiple gestation pregnancies (Pober et al., 2005; Robert et al., 1997). There are no published concordance ratios between $M Z$ and $D Z$ twins for CDH. Findings in the literature show that the majority of monozygotic twin pairs described in case reports or as part of a small series are concordant for CDH (Abe et al., 2001; Chao et al., 1997; Eichelberger et al., 1980; Gallot et al., 2003; Gencik et al., 1982; Gibbs et al., 1997; Lucas Talan et al., 1998; Machado et al., ; Mishalany \& Gordo, 1986; Watanatittan, 1983). In contrast, most twin pairs reported as part of a consecutive series are discordant (David \& Illingworth, 1976; Jancelewicz et al., 2010; Pober et al., 2005; Robert et al., 1997; Tonks et al., 2004; Torfs et al., 1992). Pober and coworkes (Pober et al., 2005) hypothesized that there is overreporting of concordantly affected twins in case reports and that $\mathrm{CDH}$, even though it can be present in both members of a monozygous twin pair, it more frequently affects only one.

The reason for low sibling recurrence (less than 1\%) and low monozygotic twin concordance of $\mathrm{CDH}$ can be due to different mechanisms, genetic and non-genetic. Genetic factors 
include incomplete penetrance, de novo chromosome abnormalities and new dominant mutations (Pober et al., 2005). It has been hypothesized that some cases of CDH may be due to mutations that interfere with normal epigenetic modifications (Austin-Ward \& Taucher, 1999). Post-zygotic de novo mutations, as well as epigenetic differences are mechanisms proven to underly monozygotic twin discordance (Kondo et al., 2002; Weksberg et al., 2002).

Recently data about the outcome of multigestational pregnancies affected by CDH have been published (Jancelewicz et al., 2010). Jancelewicz and co-workes demonstrated that the live-born mortality for multigestational infants with $\mathrm{CDH}(20-30 \%)$ was roughly the same as for the general $\mathrm{CDH}$ population (25\%). The incidence of adverse outcomes was high for both multiple and singleton pregnancies and seems to depend more on the severity of the CDH than the presence of multiple gestations. The gestational age at birth for multigestational pregnancies was found to be significantly lower than for the entire $\mathrm{CDH}$ cohort. However, prematurity is a concern in multigestational pregnancies in general accompanied by a higher morbidity and mortality for those infants. There seems to be no increases risk for the unaffected sibling in multigestational $\mathrm{CDH}$ pregnancies.

In summary, the outcome of multigestational pregnancies affected by $\mathrm{CDH}$ appear to be similar to those of singleton $\mathrm{CDH}$ pregnancies and the risk for morbidity and mortality likely depends more on $\mathrm{CDH}$ severity than the presence of multiple fetuses (Jancelewicz et al., 2010).

An example of a case of spontaneously conceived dichorionic diamniotic twin pregnancy discordant for $\mathrm{CDH}$ is presented here. The heart is on the right, there is mediastinal shift, the bowel is up in the thorax and there is a small right sided lung. The lung-to-head ratio is 2.1, which has a good prognosis (Fig. 1). The other fetus is structurally normal.

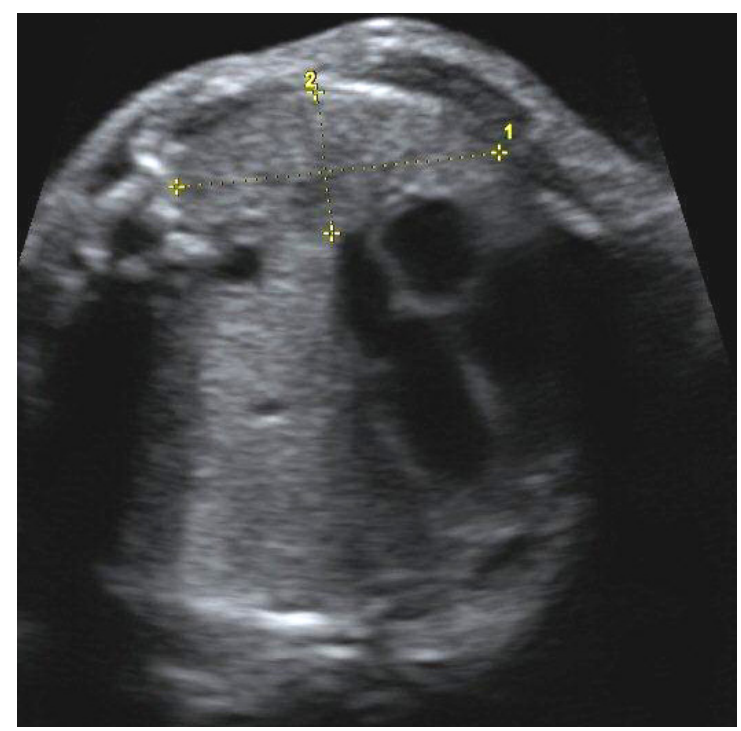

Fig. 1. CDH in a spontaneously conceived dichorionic diamniotic twin pregnancy discordant for diaphragmatic hernia at 32 weeks gestation. 


\begin{tabular}{|c|c|c|c|c|c|c|c|c|c|c|c|c|}
\hline 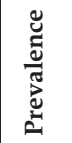 & 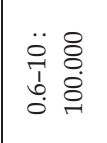 & 艺 & 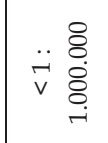 & $\begin{array}{l}8 \\
8 \\
8 \\
\stackrel{1}{1} \\
\ddot{n}\end{array}$ & 乥 & 艺 & 学 & 学 & 乥 & 乥 & 乥 & $\begin{array}{l}8 \\
8 \\
\stackrel{0}{0} \\
\ddot{-} \\
\ddot{-}\end{array}$ \\
\hline 䇅 & + & + & $\simeq$ & ' & $\simeq$ & + & + & + & + & + & + & + \\
\hline 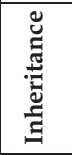 & 安 & $\vec{x}$ & 永 & $\stackrel{4}{4}$ & 永 & 学 & $\vec{x}$ & \& & \& & \& & \& & \& \\
\hline$\stackrel{n}{\tilde{J}}$ & $\begin{array}{l}\overrightarrow{0} \\
\overrightarrow{2} \\
\text { के }\end{array}$ & $\frac{\tilde{a}}{\dot{x}}$ & $\begin{array}{l}\text { ले } \\
\text { तु } \\
\stackrel{\vec{d}}{\vec{d}}\end{array}$ & 乥 & 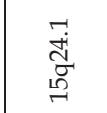 & 苛 & $\begin{array}{l}\text { ṽ } \\
\text { Nิ } \\
\hat{x}\end{array}$ & $\frac{9}{2}$ & $\frac{9}{2}$ & $\begin{array}{l}\frac{m}{2} \\
\stackrel{2}{F}\end{array}$ & $\frac{9}{2}$ & 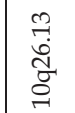 \\
\hline Uัّ & 㟧 & 营 & 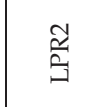 & 乥 & 交 & 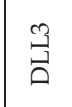 & $\begin{array}{l}0 \\
0 \\
0\end{array}$ & $\overrightarrow{3}$ & $\vec{F}$ & $\frac{F}{3}$ & $\frac{F}{3}$ & 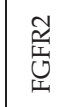 \\
\hline 芑 & 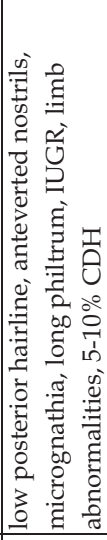 & 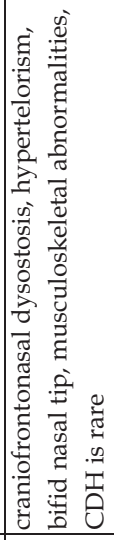 & 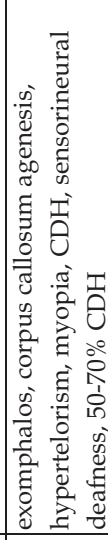 & 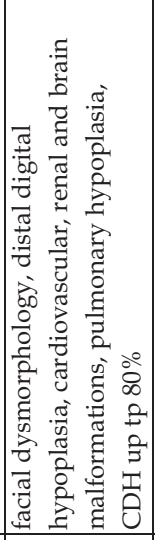 & 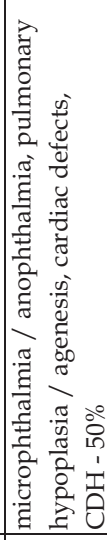 & 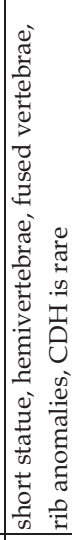 & 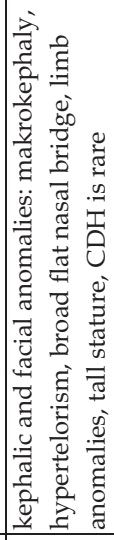 & 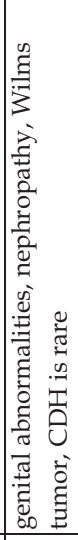 & 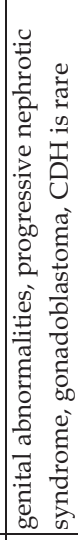 & 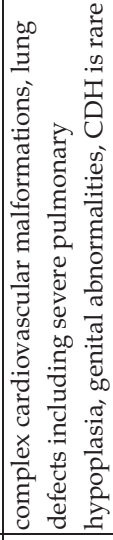 & 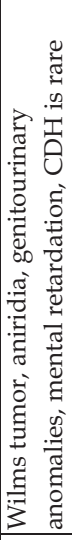 & 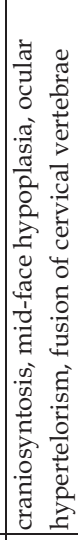 \\
\hline$\sum_{0}^{\sum}$ & $\begin{array}{l}\stackrel{R}{\sharp} \\
\text { ป }\end{array}$ & 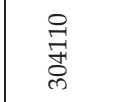 & $\underset{\text { đ̃ }}{\stackrel{\text { }}{\sharp}}$ & 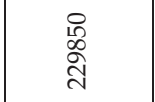 & $\begin{array}{l}\infty \\
\infty \\
\stackrel{0}{-1}\end{array}$ & 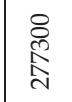 & $\begin{array}{l}\text { R } \\
\text { ô } \\
\text { ले } \\
\text { m. }\end{array}$ & 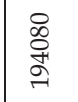 & 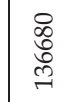 & $\begin{array}{l}\infty \\
\hat{L} \\
\stackrel{0}{0}\end{array}$ & 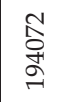 & 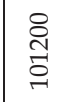 \\
\hline 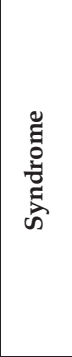 & 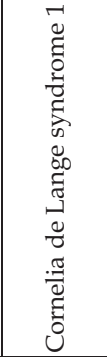 & 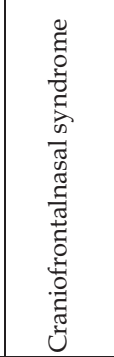 & 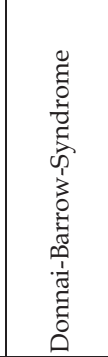 & 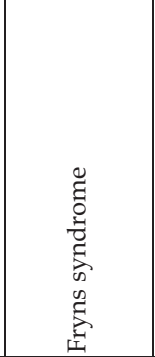 & 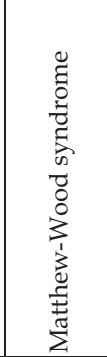 & 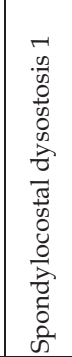 & 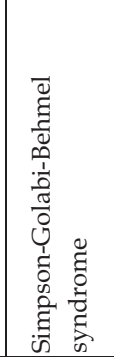 & 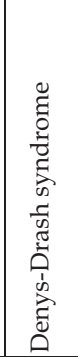 & 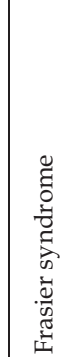 & 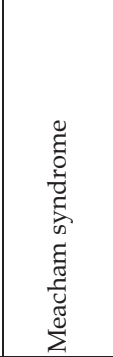 & 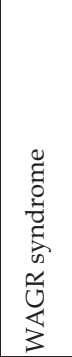 & 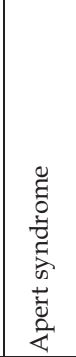 \\
\hline
\end{tabular}




\begin{tabular}{|c|c|c|c|c|c|c|c|c|c|c|c|}
\hline 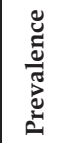 & $\begin{array}{l}\stackrel{8}{1} \\
m \\
\stackrel{-}{\sim} \\
\ddot{-}\end{array}$ & $\begin{array}{l}\stackrel{8}{8} \\
\stackrel{\text { I }}{\sim} \\
\ddot{-}\end{array}$ & 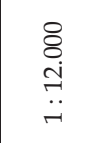 & 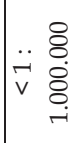 & 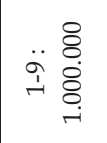 & 乥 & $\begin{array}{l}8 \\
8 \\
\stackrel{1}{1} \\
\dddot{\sim} \\
-\end{array}$ & 乥 & 乥 & 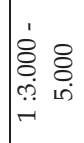 & $\begin{array}{l}8 \\
8 \\
i \\
\stackrel{0}{0} \\
\ddot{r}\end{array}$ \\
\hline 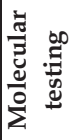 & + & + & ' & ' & + & ' & + & ' & + & & + \\
\hline 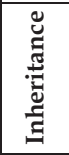 & 安 & 安 & 兄 & 过 & $\stackrel{2}{4}$ & 安 & 安 & 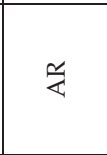 & $\vec{x}$ & 安 & 安 \\
\hline త్ర & 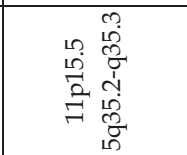 & 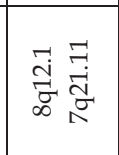 & 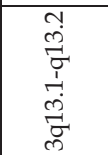 & 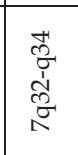 & $\begin{array}{l}\vec{g} \\
\overrightarrow{\vec{g}} \\
\vec{\sigma}\end{array}$ & 乥 & 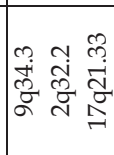 & 乥 & $\frac{\stackrel{n}{4}}{\overrightarrow{7}}$ & 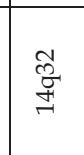 & 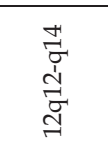 \\
\hline Uีّ & 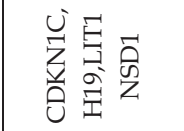 & 䓃䆓 & ถ̊ & 乥 & $\sum_{\substack{1=1 \\
\text { 至 }}}^{N}$ & 乥 & 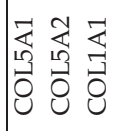 & 乥 & \begin{tabular}{l}
$Z$ \\
\multirow{2}{0}{} \\
0
\end{tabular} & 乥 & $\underset{\mathrm{Z}}{\mathrm{J}}$ \\
\hline 苞 & 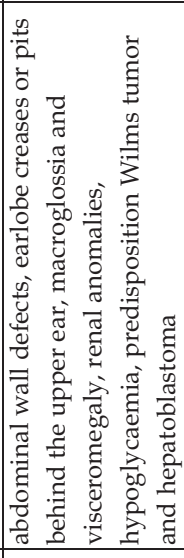 & 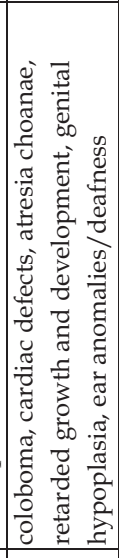 & 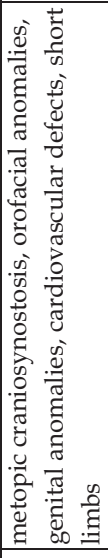 & 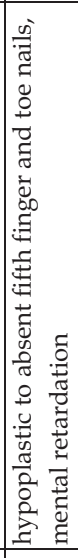 & 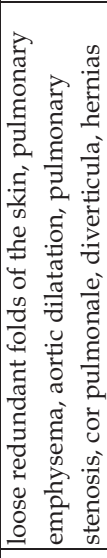 & 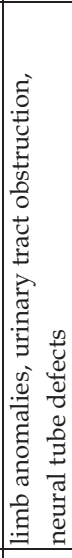 & 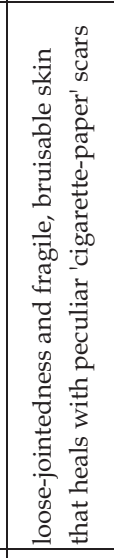 & 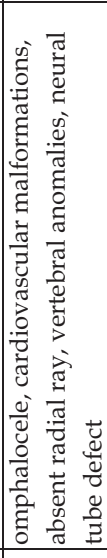 & 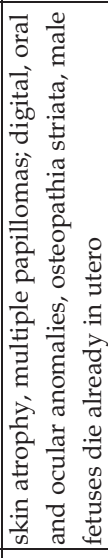 & 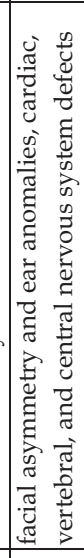 & 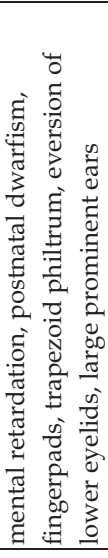 \\
\hline$\sum_{0}^{\sum}$ & 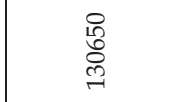 & 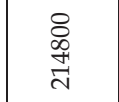 & 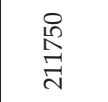 & 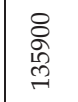 & $\begin{array}{l}8 \\
\stackrel{0}{\sigma} \\
\vec{\lambda}\end{array}$ & $\begin{array}{l}\mathcal{O} \\
\infty \\
\infty \\
\infty \\
-\end{array}$ & 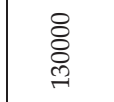 & 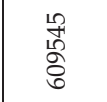 & 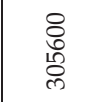 & $\begin{array}{l}\text { 웜 } \\
\text { Jै }\end{array}$ & $\begin{array}{l}\text { ๙ิ } \\
\text { કิ }\end{array}$ \\
\hline 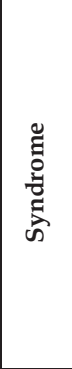 & 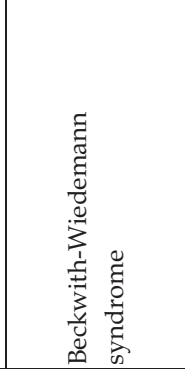 & 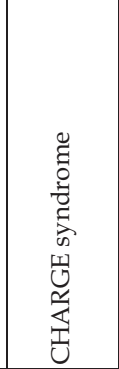 & 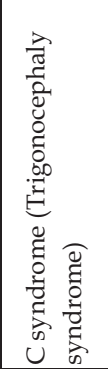 & 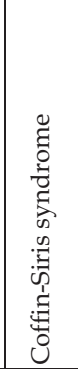 & 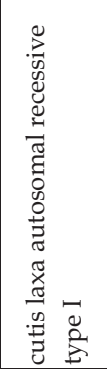 & 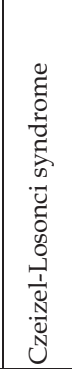 & 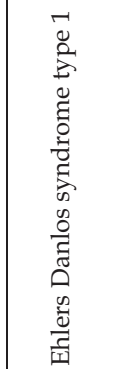 & 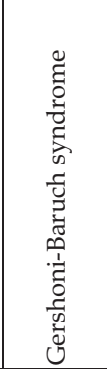 & 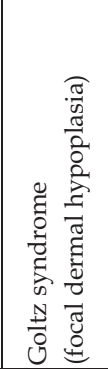 & 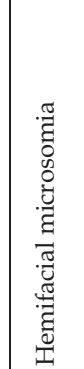 & 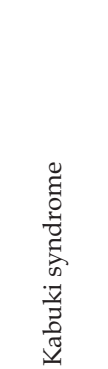 \\
\hline
\end{tabular}




\begin{tabular}{|c|c|c|c|c|c|c|c|c|c|c|c|c|}
\hline 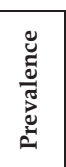 & 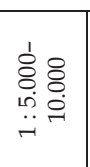 & 乥 & \begin{tabular}{|c|} 
\\
$\Xi$ \\
$\dot{\Xi}$ \\
$\varnothing$ \\
$\dot{r}$ \\
$\ddot{\vec{v}}$ \\
$\mathrm{v}$
\end{tabular} & 乥 & 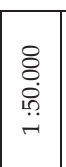 & $\begin{array}{l}8 \\
8 \\
\dot{0} \\
\dddot{1} \\
\ddot{\sigma}\end{array}$ & 乥 & 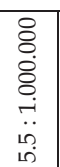 & 乥 & $\begin{array}{l}8 \\
8 \\
0 \\
0 \\
\ddot{1} \\
\ddot{m} \\
1 \\
-1\end{array}$ & 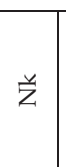 & 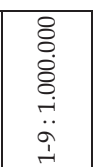 \\
\hline 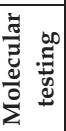 & + & ' & + & + & + & + & ' & I & ' & ' & + & \\
\hline 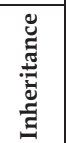 & \& & \& & $|\vec{x}|$ & 㒸 & $\vec{x}$ & $\vec{x}$ & 关 & 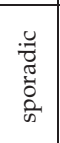 & 㒸 & 乥 & 光 & $\vec{x}$ \\
\hline 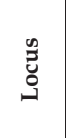 & $\begin{array}{l}\vec{Z} \\
\stackrel{\vec{Z}}{n} \\
\stackrel{n}{n}\end{array}$ & 乥 & $\left|\begin{array}{l}\tilde{1} \\
\hat{i} \\
\hat{\tilde{x}} \\
\dot{x}\end{array}\right|$ & 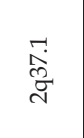 & 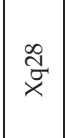 & $\begin{array}{l}\text { तี } \\
\text { ลิ } \\
\text { x. }\end{array}$ & 乥 & 乥 & 乥 & 乥 & \begin{tabular}{|l}
$\overrightarrow{0}$ \\
$\overrightarrow{\overrightarrow{2}}$ \\
$\vec{\partial}$
\end{tabular} & 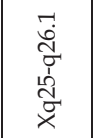 \\
\hline 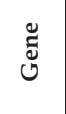 & 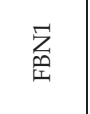 & 关 & $\left|\begin{array}{l}\mathcal{y} \\
\underset{\mathcal{T}}{0}\end{array}\right|$ & 忌 & $\sum_{\sum}^{E}$ & $\overline{\mathrm{e}}$ & 乥 & 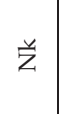 & 关 & z & Æ & 兰 \\
\hline Ŭ & 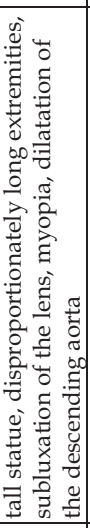 & 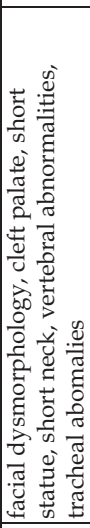 & 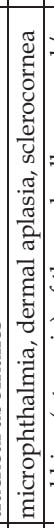 & 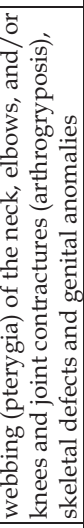 & 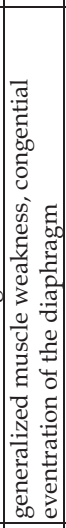 & 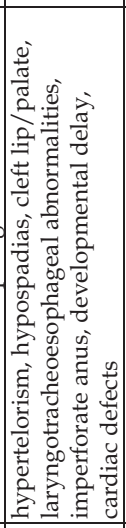 & 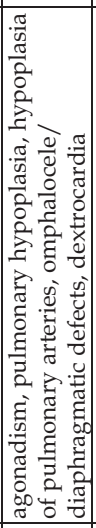 & 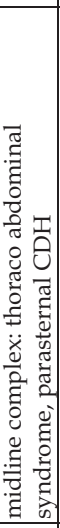 & 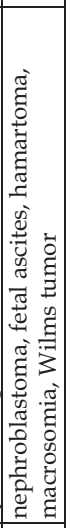 & 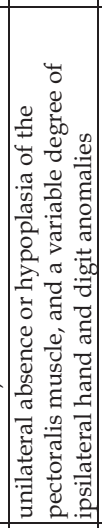 & 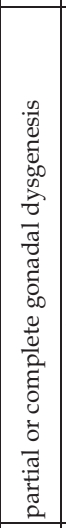 & 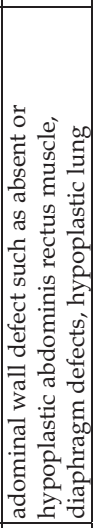 \\
\hline$\sum_{0}^{\sum}$ & $\begin{array}{l}8 \\
\stackrel{2}{\circ} \\
\stackrel{n}{n}\end{array}$ & , & 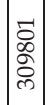 & 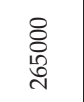 & $\begin{array}{l}\stackrel{8}{+} \\
\text { 앙 } \\
\text { ले }\end{array}$ & $\begin{array}{l}\text { ఫ } \\
\text { ఫ্ল }\end{array}$ & $\begin{array}{l}\text { : } \\
\text { त्: } \\
\text { ते }\end{array}$ & $\begin{array}{l}8 \\
\infty \\
\infty \\
\infty \\
m \\
m\end{array}$ & 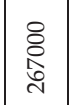 & 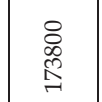 & 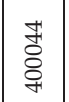 & $\begin{array}{l}\stackrel{0}{ } \\
\infty \\
\stackrel{m}{m} \\
m\end{array}$ \\
\hline 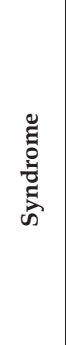 & 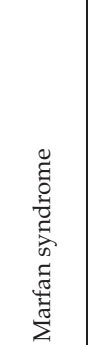 & 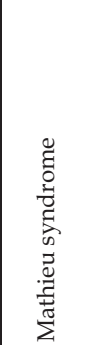 & 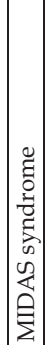 & 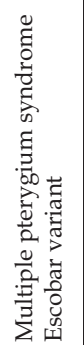 & 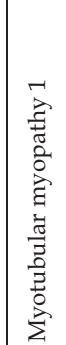 & 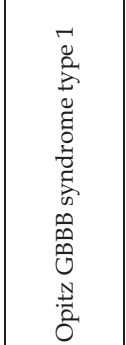 & 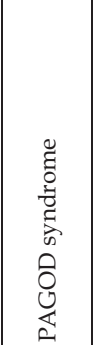 & 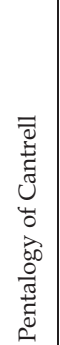 & 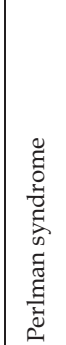 & 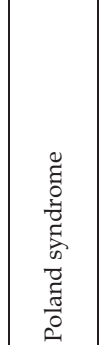 & 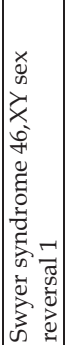 & 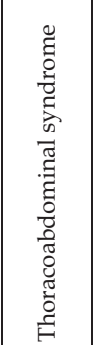 \\
\hline
\end{tabular}

AD: autosomal dominant, AR: autosomal recessive, XL: X-linked, R: Research only, NK: unknown

Table 2. CDH and associated genetic syndromes. 


\section{Pre- and postnatal diagnostic workup}

\subsection{Diagnostic investigations}

If the diagnosis of congenital $\mathrm{CDH}$ is made prenatally, a number of diagnostic steps should be offered to the patient. These steps may be helpful in classifying $\mathrm{CDH}$ as isolated or complex, the latter based on chromosmal imbalance or of syndromic origin. Important information can also be obtained from looking at the lung size, volume and dopplers. This information may be helpful in assessing survival and to make plans for the location and setting of the delivery.

\subsection{Evaluation strategies: Suggested workup for CDH patients}

- prenatal high resolution ultrasound for anomaly scanning of additional defects and fetal echocardiography by a fetal medicine specialist:

- $\quad 1^{\text {st }}$ trimester screening: nuchal translucency may be increased on ultrasound (Sebire et al., 1997).

- $\quad 2^{\text {nd }}$ trimester anomaly scanning: herniated viscera, position of the liver in the fetal thorax, absence of the normal position of the stomach bubble below the diaphragm, mediastinal shift (Stege et al., 2003; Tonks et al., 2004).

- $\quad$ polyhydramnios due to compression of esophagus (Witters et al., 2001).

- calculation of the lung-to-heart ratio (Fig. 1) as prognostic marker (Heling et al., 2005; Laudy et al., 2003; Lipshutz et al., 1997).

- color flow Doppler for demonstrating abnormal position of umbilical and portal vein, identify right-sided hernias.

- $\quad$ MRI scan calculation of lung volumes using fast spin-echo MRI provides prognosis for degree of pulmonary hypoplasia and subsequent fetal outcome (Hubbard et al., 1997; Matsuoka et al., 2003).

- $\quad$ chest $x$-ray (neonatal): bowel gas is visible above the diaphragm, mediastinal shift.

- assessment by a trained clinical geneticist (clinical examination, family history): threegeneration family history, other relatives with multiple congenital anomalies, infants who died in the perinatal period, consider examination of relatives, see medical reports.

- Chromosome analysis (karyotyping; ideally at minimum 550 bands):

- prenatally: chorionic villus sampling or amniocentesis

- postnatally: lymphocyte stimulated blood culture (non-lymphocyte-derived tissue for isochromosome 12p), when considering the diagnosis of isochromosome 12p, peripheral blood chromosome are often normal, the isochromosome 12 may be present in chromosome analyses performed on non-lymphocyte lineages such as skin fibroblasts, amniocytes, chorionic villi cells, can eventually be detected by aCGH on DNA extracted from peripheral blood.

- fluorescence in situ hybridisation (FISH), multiple color FISH.

- screening by MLPA (multiplex ligation-dependent probe amplification) for (sub) telomeric rearrangements.

- screening by high-resolution array-CGH (array-based comparative genomic hypridization): used to detect structural differences in the genome or copy number variations (CNVs), in the form of microdeletions or microduplications in prenatally diagnosed cases of $\mathrm{CDH}$ and postnatally patients with growth retardation, facial 
dysmorphology and / or major and minor anomalies in conjuction with CDH (Kantarci et al., 2006; Le Caignec et al., 2005), targeted arrays are being developed, arrays targeting known $\mathrm{CDH}$ hotspots such as $15 \mathrm{q} 26$ are available.

- $\quad$ SNP based copy number analyses.

- $\quad$ specific mutation analysis when patients fitting the phenotype of one of the syndromes: molecular gene testing for non-syndromic causes of $\mathrm{CDH}$ are not available as single gene mutations are rarely found, research testing for a FOG2 mutation is available.

- banking of fetal / neonatal metaphase pellets, DNA, cell lines and parental DNA registration in an (inter)national database, storage of fetal blood for biochemical analysis.

- physical pediatric examination of the newborn: scaphoid abdomen, diminished breath sounds ipsilateral to the side of the hernia, displacement of the heart sounds contralateral to the hernia.

- autopsy, alternatively minimal invasive autopsy or post-mortem MRI, photographs, skeletal x-rays, skin biopsy for cell line development, storage of diaphragm- and lung tissues for future functional analysis.

\section{Management at birth}

- $\quad$ planned delivery $>37$ weeks gestation.

- primary intubation.

- correction of hypercapnae and pre-ductal hypoxemia, assuring end-organ perfusion.

- infants do not need to be rushed to surgery and benefit from stabilization of respiratory and cardiovascular status prior to diaphragmatic repair.

- minimal sedation and pressure support modes of ventilation, eventually highfrequency oscillatory ventilation (HFOV)

- critical cardiopulmonary deterioration: consider extra-corporeal membrane oxygenation (ECMO), unclear whether it improves survival of $\mathrm{CDH}$

- $\quad$ ex-utero intrapartum treatment (EXIT)

- $\quad$ others (controversial): nitric oxide (NO) or phosphodiesterase inhibitors for treatment of pulmonary hypertension, delay of surgical repair, surfactant, perflubron, fetal surgery, tracheal occlusion by fetal endoscopic balloon placement (isolated CDH without chromosomal aberrations and a small LH ratio of $<0.8$ ).

\section{Conclusion}

Congenital diaphragmatic hernia is a common birth defect with an estimated incidence of 1:3000 in live births (Langham et al., 1996). Despite advances in therapy, morbidity and mortality remains high especially when associated anomalies are found. Although the etiology of most cases of $\mathrm{CDH}$ remains unknown, there is increasingly evidence that genetic factors play an important role in the development of $\mathrm{CDH}$. We presented candidate genes and genetic loci which are known to be associated with $\mathrm{CDH}$. Future research will provide more information about the genetic factors causing the development of CDH. This understanding will eventually help us to establish preventive strategies or improve therapeutic interventions for patients with $\mathrm{CDH}$. 


\section{References}

Abe, T.; Kinouchi, K.; Fukumitsu, K.; Sasaoka, N.; Taniguchi, A. \& Kitamura, S. (2001). [Perioperative management of twins with prenatally diagnosed congenital diaphragmatic hernia]. Masui, Vol.50, No.4, (Apr), pp. 394-8

Ackerman, K.G.; Herron, B.J.; Vargas, S.O.; Huang, H.; Tevosian, S.G.; Kochilas, L.; Rao, C.; Pober, B.R.; Babiuk, R.P.; Epstein, J.A.; Greer, J.J. \& Beier, D.R. (2005). Fog2 is required for normal diaphragm and lung development in mice and humans. PLoS Genet, Vol.1, No.1, (Jul), pp. 58-65

Ackerman, K.G.; Wang, J.; Luo, L.; Fujiwara, Y.; Orkin, S.H. \& Beier, D.R. (2007). Gata4 is necessary for normal pulmonary lobar development. Am J Respir Cell Mol Biol, Vol.36, No.4, (Apr), pp. 391-7

Addor, M.C.; Stefanutti, D.; Farron, F.; Meinecke, P.; Lacombe, D.; Sarlangue, J.; Prescia, G. \& Schorderet, D.F. (1995). "C" trigonocephaly syndrome with diaphragmnatic hernia. Genet Couns, Vol.6, No.2, pp. 113-20

Albanese, C.T.; Lopoo, J.; Goldstein, R.B.; Filly, R.A.; Feldstein, V.A.; Calen, P.W.; Jennings, R.W.; Farrell, J.A. \& Harrison, M.R. (1998). Fetal liver position and perinatal outcome for congenital diaphragmatic hernia. Prenat Diagn, Vol.18, No.11, (Nov), pp. 1138-42

Antonius, T.; van Bon, B.; Eggink, A.; van der Burgt, I.; Noordam, K. \& van Heijst, A. (2008). Denys-Drash syndrome and congenital diaphragmatic hernia: another case with the 1097G > A(Arg366His) mutation. Am J Med Genet A, Vol.146A, No.4, (Feb 15), pp. 496-9

Austin-Ward, E.D. \& Taucher, S.C. (1999). Familial congenital diaphragmatic hernia: is an imprinting mechanism involved? J Med Genet, Vol.36, No.7, (Jul), pp. 578-9

Ayme, S.; Julian, C.; Gambarelli, D.; Mariotti, B.; Luciani, A.; Sudan, N.; Maurin, N.; Philip, N.; Serville, F.; Carles, D. \& et al. (1989). Fryns syndrome: report on 8 new cases. Clin Genet, Vol.35, No.3, (Mar), pp. 191-201

Baglaj, M.; Spicer, R. \& Ashworth, M. (1999). Unilateral agenesis of the diaphragm: a separate entity or an extremely large defect? Pediatr Surg Int, Vol.15, No.3-4, pp. 206-9

Beighton, P.; De Paepe, A.; Steinmann, B.; Tsipouras, P. \& Wenstrup, R.J. (1998). Ehlers-Danlos syndromes: revised nosology, Villefranche, 1997. Ehlers-Danlos National Foundation (USA) and Ehlers-Danlos Support Group (UK). Am J Med Genet, Vol.77, No.1, (Apr 28), pp. 31-7

Benacerraf, B.R.; Miller, W.A. \& Frigoletto, F.D., Jr. (1988). Sonographic detection of fetuses with trisomies 13 and 18: accuracy and limitations. Am J Obstet Gynecol, Vol.158, No.2, (Feb), pp. 404-9

Berkovitz, G.D.; Fechner, P.Y.; Zacur, H.W.; Rock, J.A.; Snyder, H.M., 3rd; Migeon, C.J. \& Perlman, E.J. (1991). Clinical and pathologic spectrum of 46,XY gonadal dysgenesis: its relevance to the understanding of sex differentiation. Medicine (Baltimore), Vol.70, No.6, (Nov), pp. 375-83

Beurskens, L.W.; Tibboel, D. \& Steegers-Theunissen, R.P. (2009). Role of nutrition, lifestyle factors, and genes in the pathogenesis of congenital diaphragmatic hernia: human and animal studies. Nutr Rev, Vol.67, No.12, (Dec), pp. 719-30

Beurskens, L.W.; Tibboel, D.; Lindemans, J.; Duvekot, J.J.; Cohen-Overbeek, T.E.; Veenma, D.C.; de Klein, A.; Greer, J.J. \& Steegers-Theunissen, R.P. (2010). Retinol status of newborn infants is associated with congenital diaphragmatic hernia. Pediatrics, Vol.126, No.4, (Oct), pp. 712-20 
Biggio, J.R., Jr.; Descartes, M.D.; Carroll, A.J. \& Holt, R.L. (2004). Congenital diaphragmatic hernia: is 15q26.1-26.2 a candidate locus? Am J Med Genet A, Vol.126A, No.2, (Apr 15), pp. 183-5

Bittmann, S.; Ulus, H. \& Springer, A. (2004). Combined pentalogy of Cantrell with tetralogy of Fallot, gallbladder agenesis, and polysplenia: a case report. J Pediatr Surg, Vol.39, No.1, (Jan), pp. 107-9

Bleyl, S.B.; Moshrefi, A.; Shaw, G.M.; Saijoh, Y.; Schoenwolf, G.C.; Pennacchio, L.A. \& Slavotinek, A.M. (2007). Candidate genes for congenital diaphragmatic hernia from animal models: sequencing of FOG2 and PDGFRalpha reveals rare variants in diaphragmatic hernia patients. Eur J Hum Genet, Vol.15, No.9, (Sep), pp. 950-8

Bohn, D. (2002). Congenital diaphragmatic hernia. Am J Respir Crit Care Med, Vol.166, No.7, (Oct 1), pp. 911-5

Carmi, R.; Barbash, A. \& Mares, A.J. (1990). The thoracoabdominal syndrome (TAS): a new Xlinked dominant disorder. Am J Med Genet, Vol.36, No.1, (May), pp. 109-14

Carter, M.T.; St Pierre, S.A.; Zackai, E.H.; Emanuel, B.S. \& Boycott, K.M. (2009). Phenotypic delineation of Emanuel syndrome (supernumerary derivative 22 syndrome): Clinical features of 63 individuals. Am J Med Genet A, Vol.149A, No.8, (Aug), pp. 1712-21

Casaccia, G.; Mobili, L.; Braguglia, A.; Santoro, F. \& Bagolan, P. (2006). Distal 4p microdeletion in a case of Wolf-Hirschhorn syndrome with congenital diaphragmatic hernia. Birth Defects Res A Clin Mol Teratol, Vol.76, No.3, (Mar), pp. 210-3

Casaccia, G.; Digilio, M.C.; Seymandi, P.L. \& Bagolan, P. (2008). Congenital diaphragmatic hernia in CHARGE syndrome. Pediatr Surg Int, Vol.24, No.3, (Mar), pp. 375-8

Chao, A.S.; Cheng, P.J.; Hsueh, C. \& Soong, Y.K. (1997). The detection of right-sided congenital diaphragmatic hernia in monozygotic twins on prenatal ultrasonography. J Obstet Gynaecol Res, Vol.23, No.2, (Apr), pp. 153-5

Chassaing, N.; Lacombe, D.; Carles, D.; Calvas, P.; Saura, R. \& Bieth, E. (2003). DonnaiBarrow syndrome: four additional patients. Am J Med Genet A, Vol.121A, No.3, (Sep 1), pp. 258-62

Chitayat, D.; Sroka, H.; Keating, S.; Colby, R.S.; Ryan, G.; Toi, A.; Blaser, S.; Viero, S.; Devisme, L.; Boute-Benejean, O.; Manouvrier-Hanu, S.; Mortier, G.; Loeys, B.; Rauch, A. \& Bitoun, P. (2007). The PDAC syndrome (pulmonary hypoplasia/agenesis, diaphragmatic hernia/eventration, anophthalmia/microphthalmia, and cardiac defect) (Spear syndrome, Matthew-Wood syndrome): report of eight cases including a living child and further evidence for autosomal recessive inheritance. Am J Med Genet A, Vol.143A, No.12, (Jun 15), pp. 1268-81

Cho, H.Y.; Lee, B.S.; Kang, C.H.; Kim, W.H.; Ha, I.S.; Cheong, H.I. \& Choi, Y. (2006). Hydrothorax in a patient with Denys-Drash syndrome associated with a diaphragmatic defect. Pediatr Nephrol, Vol.21, No.12, (Dec), pp. 1909-12

Clark, R.D. \& Fenner-Gonzales, M. (1989). Apparent Fryns syndrome in a boy with a tandem duplication of 1q24-31.2. Am J Med Genet, Vol.34, No.3, (Nov), pp. 422-6

Clugston, R.D.; Klattig, J.; Englert, C.; Clagett-Dame, M.; Martinovic, J.; Benachi, A. \& Greer, J.J. (2006). Teratogen-induced, dietary and genetic models of congenital diaphragmatic hernia share a common mechanism of pathogenesis. Am J Pathol, Vol.169, No.5, (Nov), pp. 1541-9

Clugston, R.D.; Zhang, W. \& Greer, J.J. (2008). Gene expression in the developing diaphragm: significance for congenital diaphragmatic hernia. Am J Physiol Lung Cell Mol Physiol, Vol.294, No.4, (Apr), pp. L665-75 
Coffin, G.S. \& Siris, E. (1970). Mental retardation with absent fifth fingernail and terminal phalanx. Am J Dis Child, Vol.119, No.5, (May), pp. 433-9

Cohen, M.S.; Rychik, J.; Bush, D.M.; Tian, Z.Y.; Howell, L.J.; Adzick, N.S.; Flake, A.W.; Johnson, M.P.; Spray, T.L. \& Crombleholme, T.M. (2002). Influence of congenital heart disease on survival in children with congenital diaphragmatic hernia. J Pediatr, Vol.141, No.1, (Jul), pp. 25-30

Colvin, J.; Bower, C.; Dickinson, J.E. \& Sokol, J. (2005). Outcomes of congenital diaphragmatic hernia: a population-based study in Western Australia. Pediatrics, Vol.116, No.3, (Sep), pp. e356-63

Czeizel, A. \& Kovacs, M. (1985). A family study of congenital diaphragmatic defects. Am J Med Genet, Vol.21, No.1, (May), pp. 105-17

Czeizel, A. \& Losonci, A. (1987). Split hand, obstructive urinary anomalies and spina bifida or diaphragmatic defect syndrome with autosomal dominant inheritance. Hum Genet, Vol.77, No.2, (Oct), pp. 203-4

David, T.J. \& Illingworth, C.A. (1976). Diaphragmatic hernia in the south-west of England. J Med Genet, Vol.13, No.4, (Aug), pp. 253-62

Day, R. \& Fryer, A. (2003). Diaphragmatic hernia and preaxial polydactyly in spondylothoracic dysplasia. Clin Dysmorphol, Vol.12, No.4, (Oct), pp. 277-8

de Jong, G.; Rossouw, R.A. \& Retief, A.E. (1989). Ring chromosome 15 in a patient with features of Fryns' syndrome. J Med Genet, Vol.26, No.7, (Jul), pp. 469-70

Dean, J.C.; Couzin, D.A.; Gray, E.S.; Lloyd, D.J. \& Stephen, G.S. (1991). Apparent Fryns' syndrome and aneuploidy: evidence for a disturbance of the midline developmental field. Clin Genet, Vol.40, No.5, (Nov), pp. 349-52

Denamur, E.; Bocquet, N.; Baudouin, V.; Da Silva, F.; Veitia, R.; Peuchmaur, M.; Elion, J.; Gubler, M.C.; Fellous, M.; Niaudet, P. \& Loirat, C. (2000). WT1 splice-site mutations are rarely associated with primary steroid-resistant focal and segmental glomerulosclerosis. Kidney Int, Vol.57, No.5, (May), pp. 1868-72

Devriendt, K.; Deloof, E.; Moerman, P.; Legius, E.; Vanhole, C.; de Zegher, F.; Proesmans, W. \& Devlieger, H. (1995). Diaphragmatic hernia in Denys-Drash syndrome. Am J Med Genet, Vol.57, No.1, (May 22), pp. 97-101

Dillon, E.; Renwick, M. \& Wright, C. (2000). Congenital diaphragmatic herniation: antenatal detection and outcome. Br J Radiol, Vol.73, No.868, (Apr), pp. 360-5

Donadio, A.; Garavelli, L.; Banchini, G. \& Neri, G. (2000). Kabuki syndrome and diaphragmatic defects: a frequent association in non-Asian patients? Am J Med Genet, Vol.91, No.2, (Mar 13), pp. 164-5

Donnai, D. \& Barrow, M. (1993). Diaphragmatic hernia, exomphalos, absent corpus callosum, hypertelorism, myopia, and sensorineural deafness: a newly recognized autosomal recessive disorder? Am J Med Genet, Vol.47, No.5, (Oct 1), pp. 679-82

Doray, B.; Girard-Lemaire, F.; Gasser, B.; Baldauf, J.J.; De Geeter, B.; Spizzo, M.; Zeidan, C. \& Flori, E. (2002). Pallister-Killian syndrome: difficulties of prenatal diagnosis. Prenat Diagn, Vol.22, No.6, (Jun), pp. 470-7

Dott, M.M.; Wong, L.Y. \& Rasmussen, S.A. (2003). Population-based study of congenital diaphragmatic hernia: risk factors and survival in Metropolitan Atlanta, 1968-1999. Birth Defects Res A Clin Mol Teratol, Vol.67, No.4, (Apr), pp. 261-7

Eichelberger, M.R.; Kettrick, R.G.; Hoelzer, D.J.; Swedlow, D.B. \& Schnaufer, L. (1980). Agenesis of the left diaphragm: surgical repair and physiologic consequences. $J$ Pediatr Surg, Vol.15, No.4, (Aug), pp. 395-7 
Enns, G.M.; Cox, V.A.; Goldstein, R.B.; Gibbs, D.L.; Harrison, M.R. \& Golabi, M. (1998). Congenital diaphragmatic defects and associated syndromes, malformations, and chromosome anomalies: a retrospective study of 60 patients and literature review. Am J Med Genet, Vol.79, No.3, (Sep 23), pp. 215-25

Entezami, M.; Runkel, S.; Kunze, J.; Weitzel, H.K. \& Becker, R. (1998). Prenatal diagnosis of a lethal multiple pterygium syndrome type II. Case report. Fetal Diagn Ther, Vol.13, No.1, (Jan-Feb), pp. 35-8

Franceschini, P.; Guala, A.; Licata, D.; Botta, G.; Flora, F.; Angeli, G.; Di Cara, G. \& Franceschini, D. (2003). Gershoni-Baruch syndrome: report of a new family confirming autosomal recessive inheritance. Am J Med Genet A, Vol.122A, No.2, (Oct 1), pp. 174-9

Fryns, J.P.; Moerman, F.; Goddeeris, P.; Bossuyt, C. \& Van den Berghe, H. (1979). A new lethal syndrome with cloudy corneae, diaphragmatic defects and distal limb deformities. Hum Genet, Vol.50, No.1, pp. 65-70

Gallot, D.; Laurichesse, H. \& Lemery, D. (2003). Selective feticide in monochorionic twin pregnancies by ultrasound-guided umbilical cord occlusion. Ultrasound Obstet Gynecol, Vol.22, No.5, (Nov), pp. 484-8

Gencik, A.; Moser, H.; Gencikova, A. \& Kehrer, B. (1982). Familial occurrence of congenital diaphragmatic defect in three families. Helv Paediatr Acta, Vol.37, No.3, (Jun), pp. 289-93

Genevieve, D.; Amiel, J.; Viot, G.; Le Merrer, M.; Sanlaville, D.; Urtizberea, A.; Gerard, M.; Munnich, A.; Cormier-Daire, V. \& Lyonnet, S. (2004). Atypical findings in Kabuki syndrome: report of 8 patients in a series of 20 and review of the literature. Am J Med Genet A, Vol.129A, No.1, (Aug 15), pp. 64-8

Gershoni-Baruch, R.; Machoul, I.; Weiss, Y. \& Blazer, S. (1990). Unknown syndrome: radial ray defects, omphalocele, diaphragmatic hernia, and hepatic cyst. J Med Genet, Vol.27, No.6, (Jun), pp. 403-4

Ghidini, A.; Sirtori, M.; Romero, R. \& Hobbins, J.C. (1988). Prenatal diagnosis of pentalogy of Cantrell. J Ultrasound Med, Vol.7, No.10, (Oct), pp. 567-72

Gibbs, D.L.; Rice, H.E.; Farrell, J.A.; Adzick, N.S. \& Harrison, M.R. (1997). Familial diaphragmatic agenesis: an autosomal-recessive syndrome with a poor prognosis. $J$ Pediatr Surg, Vol.32, No.2, (Feb), pp. 366-8

Gillis, L.A.; McCallum, J.; Kaur, M.; DeScipio, C.; Yaeger, D.; Mariani, A.; Kline, A.D.; Li, H.H.; Devoto, M.; Jackson, L.G. \& Krantz, I.D. (2004). NIPBL mutational analysis in 120 individuals with Cornelia de Lange syndrome and evaluation of genotype-phenotype correlations. Am J Hum Genet, Vol.75, No.4, (Oct), pp. 610-23

Greenberg, F.; Copeland, K. \& Gresik, M.V. (1988). Expanding the spectrum of the Perlman syndrome. Am J Med Genet, Vol.29, No.4, (Apr), pp. 773-6

Greer, J.J.; Babiuk, R.P. \& Thebaud, B. (2003). Etiology of congenital diaphragmatic hernia: the retinoid hypothesis. Pediatr Res, Vol.53, No.5, (May), pp. 726-30

Gripp, K.W.; Donnai, D.; Clericuzio, C.L.; McDonald-McGinn, D.M.; Guttenberg, M. \& Zackai, E.H. (1997). Diaphragmatic hernia-exomphalos-hypertelorism syndrome: a new case and further evidence of autosomal recessive inheritance. Am J Med Genet, Vol.68, No.4, (Feb 11), pp. 441-4

Grogan, P.M.; Tanner, S.M.; Orstavik, K.H.; Knudsen, G.P.; Saperstein, D.S.; Vogel, H.; Barohn, R.J.; Herbelin, L.L.; McVey, A.L. \& Katz, J.S. (2005). Myopathy with skeletal 
asymmetry and hemidiaphragm elevation is caused by myotubularin mutations. Neurology, Vol.64, No.9, (May 10), pp. 1638-40

Han, X.Y.; Wu, S.S.; Conway, D.H.; Pawel, B.R.; Punnett, H.H.; Martin, R.A. \& de Chadarevian, J.P. (2000). Truncus arteriosus and other lethal internal anomalies in Goltz syndrome. Am J Med Genet, Vol.90, No.1, (Jan 3), pp. 45-8

Haspeslagh, M.; Fryns, J.P. \& van den Berghe, H. (1984). The Coffin-Siris syndrome: report of a family and further delineation. Clin Genet, Vol.26, No.4, (Oct), pp. 374-8

Heling, K.S.; Wauer, R.R.; Hammer, H.; Bollmann, R. \& Chaoui, R. (2005). Reliability of the lung-to-head ratio in predicting outcome and neonatal ventilation parameters in fetuses with congenital diaphragmatic hernia. Ultrasound Obstet Gynecol, Vol.25, No.2, (Feb), pp. 112-8

Holder, A.M.; Klaassens, M.; Tibboel, D.; de Klein, A.; Lee, B. \& Scott, D.A. (2007). Genetic factors in congenital diaphragmatic hernia. Am J Hum Genet, Vol.80, No.5, (May), pp. $825-45$

Hou, J.W. \& Wang, T.R. (1999). Extreme Poland anomaly associated with congenital diaphragmatic hernia. Eur J Pediatr, Vol.158, No.5, (May), pp. 433-4

Hoyer, J.; Kraus, C.; Hammersen, G.; Geppert, J.P. \& Rauch, A. (2009). Lethal cutis laxa with contractural arachnodactyly, overgrowth and soft tissue bleeding due to a novel homozygous fibulin-4 gene mutation. Clin Genet, Vol.76, No.3, (Sep), pp. 276-81

Hubbard, A.M.; Adzick, N.S.; Crombleholme, T.M. \& Haselgrove, J.C. (1997). Left-sided congenital diaphragmatic hernia: value of prenatal MR imaging in preparation for fetal surgery. Radiology, Vol.203, No.3, (Jun), pp. 636-40

Hucthagowder, V.; Sausgruber, N.; Kim, K.H.; Angle, B.; Marmorstein, L.Y. \& Urban, Z. (2006). Fibulin-4: a novel gene for an autosomal recessive cutis laxa syndrome. Am J Hum Genet, Vol.78, No.6, (Jun), pp. 1075-80

Jancelewicz, T.; Vu, L.T.; Keller, R.L.; Jelin, E.B.; Bratton, B.J.; Townsend, T.C. \& Nobuhara, K.K. (2010). Outcomes of multigestational pregnancies affected by congenital diaphragmatic hernia. J Pediatr Surg, Vol.45, No.9, (Sep), pp. 1753-8

Kadir, R.A.; Hastings, R. \& Economides, D.L. (1997). Prenatal diagnosis of supernumerary chromosome derivative (22) due to maternal balanced translocation in association with diaphragmatic hernia: a case report. Prenat Diagn, Vol.17, No.8, (Aug), pp. 761-4

Kantarci, S.; Casavant, D.; Prada, C.; Russell, M.; Byrne, J.; Haug, L.W.; Jennings, R.; Manning, S.; Blaise, F.; Boyd, T.K.; Fryns, J.P.; Holmes, L.B.; Donahoe, P.K.; Lee, C.; Kimonis, V. \& Pober, B.R. (2006). Findings from aCGH in patients with congenital diaphragmatic hernia (CDH): a possible locus for Fryns syndrome. Am J Med Genet A, Vol.140, No.1, (Jan 1), pp. 17-23

Kantarci, S.; Al-Gazali, L.; Hill, R.S.; Donnai, D.; Black, G.C.; Bieth, E.; Chassaing, N.; Lacombe, D.; Devriendt, K.; Teebi, A.; Loscertales, M.; Robson, C.; Liu, T.; MacLaughlin, D.T.; Noonan, K.M.; Russell, M.K.; Walsh, C.A.; Donahoe, P.K. \& Pober, B.R. (2007). Mutations in LRP2, which encodes the multiligand receptor megalin, cause Donnai-Barrow and facio-oculo-acoustico-renal syndromes. Nat Genet, Vol.39, No.8, (Aug), pp. 957-9

Kantarci, S.; Ackerman, K.G.; Russell, M.K.; Longoni, M.; Sougnez, C.; Noonan, K.M.; Hatchwell, E.; Zhang, X.; Pieretti Vanmarcke, R.; Anyane-Yeboa, K.; Dickman, P.; Wilson, J.; Donahoe, P.K. \& Pober, B.R. (2010). Characterization of the chromosome $1 \mathrm{q} 41 \mathrm{q} 42.12$ region, and the candidate gene DISP1, in patients with $\mathrm{CDH}$. Am J Med Genet A, Vol.152A, No.10, (Oct), pp. 2493-504 
Keijzer, R.; Liu, J.; Deimling, J.; Tibboel, D. \& Post, M. (2000). Dual-hit hypothesis explains pulmonary hypoplasia in the nitrofen model of congenital diaphragmatic hernia. Am J Pathol, Vol.156, No.4, (Apr), pp. 1299-306

Kennerknecht, I.; Sorgo, W.; Oberhoffer, R.; Teller, W.M.; Mattfeldt, T.; Negri, G. \& Vogel, W. (1993). Familial occurrence of agonadism and multiple internal malformations in phenotypically normal girls with 46,XY and 46,XX karyotypes, respectively: a new autosomal recessive syndrome. Am J Med Genet, Vol.47, No.8, (Dec 1), pp. 1166-70

Kent, A.; Simpson, E.; Ellwood, D. \& Silink, M. (2004). 46,XY sex-reversal (Swyer syndrome) and congenital diaphragmatic hernia. Am J Med Genet A, Vol.131, No.1, (Nov 15), pp. 103-5

Killeen, O.G.; Kelehan, P. \& Reardon, W. (2002). Double vagina with sex reversal, congenital diaphragmatic hernia, pulmonary and cardiac malformations--another case of Meacham syndrome. Clin Dysmorphol, Vol.11, No.1, (Jan), pp. 25-8

Klaassens, M.; van Dooren, M.; Eussen, H.J.; Douben, H.; den Dekker, A.T.; Lee, C.; Donahoe, P.K.; Galjaard, R.J.; Goemaere, N.; de Krijger, R.R.; Wouters, C.; Wauters, J.; Oostra, B.A.; Tibboel, D. \& de Klein, A. (2005). Congenital diaphragmatic hernia and chromosome 15q26: determination of a candidate region by use of fluorescent in situ hybridization and array-based comparative genomic hybridization. Am J Hum Genet, Vol.76, No.5, (May), pp. 877-82

Klaassens, M.; Galjaard, R.J.; Scott, D.A.; Bruggenwirth, H.T.; van Opstal, D.; Fox, M.V.; Higgins, R.R.; Cohen-Overbeek, T.E.; Schoonderwaldt, E.M.; Lee, B.; Tibboel, D. \& de Klein, A. (2007). Prenatal detection and outcome of congenital diaphragmatic hernia $(\mathrm{CDH})$ associated with deletion of chromosome 15q26: two patients and review of the literature. Am J Med Genet A, Vol.143A, No.18, (Sep 15), pp. 2204-12

Klaassens, M.; de Klein, A. \& Tibboel, D. (2009). The etiology of congenital diaphragmatic hernia: still largely unknown? Eur J Med Genet, Vol.52, No.5, (Sep-Oct), pp. 281-6

Kondo, S.; Schutte, B.C.; Richardson, R.J.; Bjork, B.C.; Knight, A.S.; Watanabe, Y.; Howard, E.; de Lima, R.L.; Daack-Hirsch, S.; Sander, A.; McDonald-McGinn, D.M.; Zackai, E.H.; Lammer, E.J.; Aylsworth, A.S.; Ardinger, H.H.; Lidral, A.C.; Pober, B.R.; Moreno, L.; Arcos-Burgos, M.; Valencia, C.; Houdayer, C.; Bahuau, M.; Moretti-Ferreira, D.; Richieri-Costa, A.; Dixon, M.J. \& Murray, J.C. (2002). Mutations in IRF6 cause Van der Woude and popliteal pterygium syndromes. Nat Genet, Vol.32, No.2, (Oct), pp. 285-9

Krassikoff, N. \& Sekhon, G.S. (1990). Terminal deletion of $6 \mathrm{q}$ and Fryns syndrome: a microdeletion/syndrome pair? Am J Med Genet, Vol.36, No.3, (Jul), pp. 363-4

Lally, K.P.; Lally, P.A.; Lasky, R.E.; Tibboel, D.; Jaksic, T.; Wilson, J.M.; Frenckner, B.; Van Meurs, K.P.; Bohn, D.J.; Davis, C.F. \& Hirschl, R.B. (2007). Defect size determines survival in infants with congenital diaphragmatic hernia. Pediatrics, Vol.120, No.3, (Sep), pp. e651-7

Langham, M.R., Jr.; Kays, D.W.; Ledbetter, D.J.; Frentzen, B.; Sanford, L.L. \& Richards, D.S. (1996). Congenital diaphragmatic hernia. Epidemiology and outcome. Clin Perinatol, Vol.23, No.4, (Dec), pp. 671-88

Laporte, J.; Hu, L.J.; Kretz, C.; Mandel, J.L.; Kioschis, P.; Coy, J.F.; Klauck, S.M.; Poustka, A. \& Dahl, N. (1996). A gene mutated in X-linked myotubular myopathy defines a new putative tyrosine phosphatase family conserved in yeast. Nat Genet, Vol.13, No.2, (Jun), pp. 175-82

Laudy, J.A.; Van Gucht, M.; Van Dooren, M.F.; Wladimiroff, J.W. \& Tibboel, D. (2003). Congenital diaphragmatic hernia: an evaluation of the prognostic value of the 
lung-to-head ratio and other prenatal parameters. Prenat Diagn, Vol.23, No.8, (Aug), pp. 634-9

Le Caignec, C.; Boceno, M.; Saugier-Veber, P.; Jacquemont, S.; Joubert, M.; David, A.; Frebourg, T. \& Rival, J.M. (2005). Detection of genomic imbalances by array based comparative genomic hybridisation in fetuses with multiple malformations. $J$ Med Genet, Vol.42, No.2, (Feb), pp. 121-8

Li, M.; Shuman, C.; Fei, Y.L.; Cutiongco, E.; Bender, H.A.; Stevens, C.; Wilkins-Haug, L.; Day-Salvatore, D.; Yong, S.L.; Geraghty, M.T.; Squire, J. \& Weksberg, R. (2001). GPC3 mutation analysis in a spectrum of patients with overgrowth expands the phenotype of Simpson-Golabi-Behmel syndrome. Am J Med Genet, Vol.102, No.2, (Aug 1), pp. 161-8

Lin, A.E.; Pober, B.R.; Mullen, M.P. \& Slavotinek, A.M. (2005). Cardiovascular malformations in Fryns syndrome: is there a pathogenic role for neural crest cells? Am J Med Genet A, Vol.139, No.3, (Dec 15), pp. 186-93

Lin, A.E.; Pober, B.R. \& Adatia, I. (2007). Congenital diaphragmatic hernia and associated cardiovascular malformations: type, frequency, and impact on management. Am J Med Genet C Semin Med Genet, Vol.145C, No.2, (May 15), pp. 201-16

Lipshutz, G.S.; Albanese, C.T.; Feldstein, V.A.; Jennings, R.W.; Housley, H.T.; Beech, R.; Farrell, J.A. \& Harrison, M.R. (1997). Prospective analysis of lung-to-head ratio predicts survival for patients with prenatally diagnosed congenital diaphragmatic hernia. $J$ Pediatr Surg, Vol.32, No.11, (Nov), pp. 1634-6

Lucas Talan, M.; Garcia, L.; Cortiella, P.; Lopez Gil, V.; Perapoch, J. \& Miranda, L. (1998). [Delivery of twins with diaphragmatic hernia]. Rev Esp Anestesiol Reanim, Vol.45, No.3, (Mar), pp. 114-5

Lurie, I.W. (2003). Where to look for the genes related to diaphragmatic hernia? Genet Couns, Vol.14, No.1, pp. 75-93

Macayran, J.F.; Doroshow, R.W.; Phillips, J.; Sinow, R.M.; Furst, B.A.; Smith, L.M. \& Lin, H.J. (2002). PAGOD syndrome: eighth case and comparison to animal models of congenital vitamin A deficiency. Am J Med Genet, Vol.108, No.3, (Mar 15), pp. 229-34

Machado, A.P.; Ramalho, C.; Portugal, R.; Brandao, O.; Carvalho, B.; Carvalho, F.; Matias, A. \& Montenegro, N. Concordance for bilateral congenital diaphragmatic hernia in a monozygotic dichorionic twin pair - first clinical report. Fetal Diagn Ther, Vol.27, No.2, pp. 106-9

Manouvrier-Hanu, S.; Devisme, L.; Vaast, P.; Boute-Benejean, O. \& Farriaux, J.P. (1996). Fryns syndrome and erupted teeth in a 24 -weeks-old fetus. Genet Couns, Vol.7, No.2, pp. 131-4

Manouvrier, S.; Espinasse, M.; Vaast, P.; Boute, O.; Farre, I.; Dupont, F.; Puech, F.; Gosselin, B. \& Farriaux, J.P. (1996). Brachmann-de Lange syndrome: pre- and postnatal findings. Am J Med Genet, Vol.62, No.3, (Mar 29), pp. 268-73

Martinez-Frias, M.L.; Bermejo, E.; Felix, V.; Jimenez, N.; Gomez-Ullate, J.; Lopez, J.A.; Aparicio, P.; Ayala, A.; Gairi, J.M.; Galan, E.; Suarez, M.E.; Penas, A.; de Tapia, J.M.; Nieto, C. \& de la Serna, E. (1998). [Brachmann-de-Lange syndrome in our population: clinical and epidemiological characteristics]. An Esp Pediatr, Vol.48, No.3, (Mar), pp. 293-8

Masturzo, B.; Kalache, K.D.; Cockell, A.; Pierro, A. \& Rodeck, C.H. (2001). Prenatal diagnosis of an ectopic intrathoracic kidney in right-sided congenital diaphragmatic hernia using color Doppler ultrasonography. Ultrasound Obstet Gynecol, Vol.18, No.2, (Aug), pp. 173-4 
Mathieu, M.; De Broca, A.; Bony, H. \& Piussan, C. (1993). A familial syndrome with micrognathia, cleft palate, short neck and stature, vertebral anomalies and mental retardation. Genet Couns, Vol.4, No.4, pp. 299-303

Matsuoka, S.; Takeuchi, K.; Yamanaka, Y.; Kaji, Y.; Sugimura, K. \& Maruo, T. (2003). Comparison of magnetic resonance imaging and ultrasonography in the prenatal diagnosis of congenital thoracic abnormalities. Fetal Diagn Ther, Vol.18, No.6, (NovDec), pp. 447-53

McGillivray, B.C. \& Lowry, R.B. (1977). Poland syndrome in British Columbia: incidence and reproductive experience of affected persons. Am J Med Genet, Vol.1, No.1, pp. 65-74

Meacham, L.R.; Winn, K.J.; Culler, F.L. \& Parks, J.S. (1991). Double vagina, cardiac, pulmonary, and other genital malformations with 46,XY karyotype. Am J Med Genet, Vol.41, No.4, (Dec 15), pp. 478-81

Mishalany, H. \& Gordo, J. (1986). Congenital diaphragmatic hernia in monozygotic twins. J Pediatr Surg, Vol.21, No.4, (Apr), pp. 372-4

Moerman, P.; Fryns, J.P.; Devlieger, H.; Van Assche, A. \& Lauweryns, J. (1987). Congenital eventration of the diaphragm: an unusual cause of intractable neonatal respiratory distress with variable etiology. Am J Med Genet, Vol.27, No.1, (May), pp. 213-8

Moore, A.W.; Schedl, A.; McInnes, L.; Doyle, M.; Hecksher-Sorensen, J. \& Hastie, N.D. (1998). YAC transgenic analysis reveals Wilms' tumour 1 gene activity in the proliferating coelomic epithelium, developing diaphragm and limb. Mech Dev, Vol.79, No.1-2, (Dec), pp. 169-84

Morgan, N.V.; Brueton, L.A.; Cox, P.; Greally, M.T.; Tolmie, J.; Pasha, S.; Aligianis, I.A.; van Bokhoven, H.; Marton, T.; Al-Gazali, L.; Morton, J.E.; Oley, C.; Johnson, C.A.; Trembath, R.C.; Brunner, H.G. \& Maher, E.R. (2006). Mutations in the embryonal subunit of the acetylcholine receptor (CHRNG) cause lethal and Escobar variants of multiple pterygium syndrome. Am J Hum Genet, Vol.79, No.2, (Aug), pp. 390-5

Mowery-Rushton, P.A.; Stadler, M.P.; Kochmar, S.J.; McPherson, E.; Surti, U. \& Hogge, W.A. (1997). The use of interphase FISH for prenatal diagnosis of Pallister-Killian syndrome. Prenat Diagn, Vol.17, No.3, (Mar), pp. 255-65

Neri, G.; Gurrieri, F.; Zanni, G. \& Lin, A. (1998). Clinical and molecular aspects of the SimpsonGolabi-Behmel syndrome. Am J Med Genet, Vol.79, No.4, (Oct 2), pp. 279-83

Neville, H.L.; Jaksic, T.; Wilson, J.M.; Lally, P.A.; Hardin, W.D., Jr.; Hirschl, R.B.; Langham, M.R., Jr. \& Lally, K.P. (2002). Fryns syndrome in children with congenital diaphragmatic hernia. J Pediatr Surg, Vol.37, No.12, (Dec), pp. 1685-7

Niikawa, N.; Matsuura, N.; Fukushima, Y.; Ohsawa, T. \& Kajii, T. (1981). Kabuki make-up syndrome: a syndrome of mental retardation, unusual facies, large and protruding ears, and postnatal growth deficiency. J Pediatr, Vol.99, No.4, (Oct), pp. 565-9

Panda, B.; Rosenberg, V.; Cornfeld, D. \& Stiller, R. (2009). Prenatal diagnosis of ectopic intrathoracic kidney in a fetus with a left diaphragmatic hernia. J Clin Ultrasound, Vol.37, No.1, (Jan), pp. 47-9

Parmar, R.C.; Tullu, M.S.; Bavdekar, S.B. \& Borwankar, S.S. (2001). Morgagni hernia with Down syndrome: a rare association -- case report and review of literature. J Postgrad Med, Vol.47, No.3, (Jul-Sep), pp. 188-90

Pasutto, F.; Sticht, H.; Hammersen, G.; Gillessen-Kaesbach, G.; Fitzpatrick, D.R.; Nurnberg, G.; Brasch, F.; Schirmer-Zimmermann, H.; Tolmie, J.L.; Chitayat, D.; Houge, G.; Fernandez-Martinez, L.; Keating, S.; Mortier, G.; Hennekam, R.C.; von der Wense, A.; Slavotinek, A.; Meinecke, P.; Bitoun, P.; Becker, C.; Nurnberg, P.; Reis, A. \& Rauch, A. 
(2007). Mutations in STRA6 cause a broad spectrum of malformations including anophthalmia, congenital heart defects, diaphragmatic hernia, alveolar capillary dysplasia, lung hypoplasia, and mental retardation. Am J Hum Genet, Vol.80, No.3, (Mar), pp. 550-60

Perlman, M. (1986). Perlman syndrome: familial renal dysplasia with Wilms tumor, fetal gigantism, and multiple congenital anomalies. Am J Med Genet, Vol.25, No.4, (Dec), pp. $793-5$

Pilia, G.; Hughes-Benzie, R.M.; MacKenzie, A.; Baybayan, P.; Chen, E.Y.; Huber, R.; Neri, G.; Cao, A.; Forabosco, A. \& Schlessinger, D. (1996). Mutations in GPC3, a glypican gene, cause the Simpson-Golabi-Behmel overgrowth syndrome. Nat Genet, Vol.12, No.3, (Mar), pp. 241-7

Pober, B.R.; Russell, M.K. \& Ackerman, K.G. (1993). Congenital Diaphragmatic Hernia Overview. pp.

Pober, B.R.; Lin, A.; Russell, M.; Ackerman, K.G.; Chakravorty, S.; Strauss, B.; Westgate, M.N.; Wilson, J.; Donahoe, P.K. \& Holmes, L.B. (2005). Infants with Bochdalek diaphragmatic hernia: sibling precurrence and monozygotic twin discordance in a hospital-based malformation surveillance program. Am J Med Genet A, Vol.138A, No.2, (Oct 1), pp. 81-8

Pober, B.R. (2008). Genetic aspects of human congenital diaphragmatic hernia. Clin Genet, Vol.74, No.1, (Jul), pp. 1-15

Revencu, N.; Quenum, G.; Detaille, T.; Verellen, G.; De Paepe, A. \& Verellen-Dumoulin, C. (2004). Congenital diaphragmatic eventration and bilateral uretero-hydronephrosis in a patient with neonatal Marfan syndrome caused by a mutation in exon 25 of the FBN1 gene and review of the literature. Eur J Pediatr, Vol.163, No.1, (Jan), pp. 33-7

Robert, E.; Kallen, B. \& Harris, J. (1997). The epidemiology of diaphragmatic hernia. Eur J Epidemiol, Vol.13, No.6, (Sep), pp. 665-73

Rodriguez, L.M.; Garcia-Garcia, I.; Correa-Rivas, M.S. \& Garcia-Fragoso, L. (2004). Pulmonary hypoplasia in Jarcho-Levin syndrome. P R Health Sci J, Vol.23, No.1, (Mar), pp. 65-7

Rollnick, B.R. \& Kaye, C.I. (1983). Hemifacial microsomia and variants: pedigree data. Am J Med Genet, Vol.15, No.2, (Jun), pp. 233-53

Saavedra, D.; Richieri-Costa, A.; Guion-Almeida, M.L. \& Cohen, M.M., Jr. (1996). Craniofrontonasal syndrome: study of 41 patients. Am J Med Genet, Vol.61, No.2, (Jan 11), pp. 147-51

Sakazume, S.; Okamoto, N.; Yamamoto, T.; Kurosawa, K.; Numabe, H.; Ohashi, Y.; Kako, Y.; Nagai, T. \& Ohashi, H. (2007). GPC3 mutations in seven patients with SimpsonGolabi-Behmel syndrome. Am J Med Genet A, Vol.143A, No.15, (Aug 1), pp. 1703-7

Scott, D.A.; Cooper, M.L.; Stankiewicz, P.; Patel, A.; Potocki, L. \& Cheung, S.W. (2005). Congenital diaphragmatic hernia in WAGR syndrome. Am J Med Genet A, Vol.134, No.4, (May 1), pp. 430-3

Sebire, N.J.; Snijders, R.J.; Davenport, M.; Greenough, A. \& Nicolaides, K.H. (1997). Fetal nuchal translucency thickness at 10-14 weeks' gestation and congenital diaphragmatic hernia. Obstet Gynecol, Vol.90, No.6, (Dec), pp. 943-6

Sergi, C.; Schulze, B.R.; Hager, H.D.; Beedgen, B.; Zilow, E.; Linderkamp, O.; Otto, H.F. \& Tariverdian, G. (1998). Wolf-Hirschhorn syndrome: case report and review of the chromosomal aberrations associated with diaphragmatic defects. Pathologica, Vol.90, No.3, (Jun), pp. 285-93 
Shaffer, L.G.; Theisen, A.; Bejjani, B.A.; Ballif, B.C.; Aylsworth, A.S.; Lim, C.; McDonald, M.; Ellison, J.W.; Kostiner, D.; Saitta, S. \& Shaikh, T. (2007). The discovery of microdeletion syndromes in the post-genomic era: review of the methodology and characterization of a new 1q41q42 microdeletion syndrome. Genet Med, Vol.9, No.9, (Sep), pp. 607-16

Shehata, S.M.; El-Banna, I.A.; Gaber, A.A. \& El-Samongy, A.M. (2000). Spondylothoracic dysplasia with diaphragmatic defect: a case report with literature review. Eur J Pediatr Surg, Vol.10, No.5, (Oct), pp. 337-9

Skari, H.; Bjornland, K.; Haugen, G.; Egeland, T. \& Emblem, R. (2000). Congenital diaphragmatic hernia: a meta-analysis of mortality factors. J Pediatr Surg, Vol.35, No.8, (Aug), pp. 1187-97

Slavotinek, A.M. (2004). Fryns syndrome: a review of the phenotype and diagnostic guidelines. Am J Med Genet A, Vol.124A, No.4, (Feb 1), pp. 427-33

Slavotinek, A.M. (2007). Single gene disorders associated with congenital diaphragmatic hernia. Am J Med Genet C Semin Med Genet, Vol.145C, No.2, (May 15), pp. 172-83

Snijders, R.J.M. \& Nicolaides, K.H. (1996). Fetal abnormalities The Parthenon Publishing Group, 1-85070-610-7, London, UK

Song, A. \& McLeary, M.S. (2000). MR imaging of pentalogy of Cantrell variant with an intact diaphragm and pericardium. Pediatr Radiol, Vol.30, No.9, (Sep), pp. 638-9

Stege, G.; Fenton, A. \& Jaffray, B. (2003). Nihilism in the 1990s: the true mortality of congenital diaphragmatic hernia. Pediatrics, Vol.112, No.3 Pt 1, (Sep), pp. 532-5

Steiner, R.D.; St, J.D.P.; Hopkin, R.J.; Kozielski, R. \& Bove, K.E. (2002). Combination of diaphragmatic eventration and microphthalmia/anophthalmia is probably nonrandom. Am J Med Genet, Vol.108, No.1, (Feb 15), pp. 45-50

Struthers, J.L.; Cuthbert, C.D. \& Khalifa, M.M. (1999). Parental origin of the isochromosome $12 \mathrm{p}$ in Pallister-Killian syndrome: molecular analysis of one patient and review of the reported cases. Am J Med Genet, Vol.84, No.2, (May 21), pp. 111-5

Suri, M.; Kelehan, P.; O'Neill, D.; Vadeyar, S.; Grant, J.; Ahmed, S.F.; Tolmie, J.; McCann, E.; Lam, W.; Smith, S.; Fitzpatrick, D.; Hastie, N.D. \& Reardon, W. (2007). WT1 mutations in Meacham syndrome suggest a coelomic mesothelial origin of the cardiac and diaphragmatic malformations. Am J Med Genet A, Vol.143A, No.19, (Oct 1), pp. 2312-20

Tongsong, T.; Sirichotiyakul, S.; Wanapirak, C. \& Chanprapaph, P. (2002). Sonographic features of trisomy 18 at midpregnancy. J Obstet Gynaecol Res, Vol.28, No.5, (Oct), pp. $245-50$

Tonks, A.; Wyldes, M.; Somerset, D.A.; Dent, K.; Abhyankar, A.; Bagchi, I.; Lander, A.; Roberts, E. \& Kilby, M.D. (2004). Congenital malformations of the diaphragm: findings of the West Midlands Congenital Anomaly Register 1995 to 2000. Prenat Diagn, Vol.24, No.8, (Aug), pp. 596-604

Torfs, C.P.; Curry, C.J.; Bateson, T.F. \& Honore, L.H. (1992). A population-based study of congenital diaphragmatic hernia. Teratology, Vol.46, No.6, (Dec), pp. 555-65

Toyama, W.M. (1972). Combined congenital defects of the anterior abdominal wall, sternum, diaphragm, pericardium, and heart: a case report and review of the syndrome. Pediatrics, Vol.50, No.5, (Nov), pp. 778-92

Turleau, C.; de Grouchy, J.; Chavin-Colin, F.; Martelli, H.; Voyer, M. \& Charlas, R. (1984). Trisomy 11p15 and Beckwith-Wiedemann syndrome. A report of two cases. Hum Genet, Vol.67, No.2, pp. 219-21 
van Dooren, M.F.; Brooks, A.S.; Tibboel, D. \& Torfs, C.P. (2003). Association of congenital diaphragmatic hernia with limb-reduction defects. Birth Defects Res A Clin Mol Teratol, Vol.67, No.8, (Aug), pp. 578-84

Vasudevan, P.C.; Twigg, S.R.; Mulliken, J.B.; Cook, J.A.; Quarrell, O.W. \& Wilkie, A.O. (2006). Expanding the phenotype of craniofrontonasal syndrome: two unrelated boys with EFNB1 mutations and congenital diaphragmatic hernia. Eur J Hum Genet, Vol.14, No.7, (Jul), pp. 884-7

Vissers, L.E.; van Ravenswaaij, C.M.; Admiraal, R.; Hurst, J.A.; de Vries, B.B.; Janssen, I.M.; van der Vliet, W.A.; Huys, E.H.; de Jong, P.J.; Hamel, B.C.; Schoenmakers, E.F.; Brunner, H.G.; Veltman, J.A. \& van Kessel, A.G. (2004). Mutations in a new member of the chromodomain gene family cause CHARGE syndrome. Nat Genet, Vol.36, No.9, (Sep), pp. 955-7

Watanatittan, S. (1983). Congenital diaphragmatic hernia in identical twins. J Pediatr Surg, Vol.18, No.5, (Oct), pp. 628-9

Weksberg, R.; Shuman, C.; Caluseriu, O.; Smith, A.C.; Fei, Y.L.; Nishikawa, J.; Stockley, T.L.; Best, L.; Chitayat, D.; Olney, A.; Ives, E.; Schneider, A.; Bestor, T.H.; Li, M.; Sadowski, P. \& Squire, J. (2002). Discordant KCNQ1OT1 imprinting in sets of monozygotic twins discordant for Beckwith-Wiedemann syndrome. Hum Mol Genet, Vol.11, No.11, (May 15), pp. 1317-25

Weksberg, R.; Shuman, C. \& Beckwith, J.B. (2010). Beckwith-Wiedemann syndrome. Eur J Hum Genet, Vol.18, No.1, (Jan), pp. 8-14

Wieland, I.; Jakubiczka, S.; Muschke, P.; Cohen, M.; Thiele, H.; Gerlach, K.L.; Adams, R.H. \& Wieacker, P. (2004). Mutations of the ephrin-B1 gene cause craniofrontonasal syndrome. Am J Hum Genet, Vol.74, No.6, (Jun), pp. 1209-15

Wimplinger, I.; Morleo, M.; Rosenberger, G.; Iaconis, D.; Orth, U.; Meinecke, P.; Lerer, I.; Ballabio, A.; Gal, A.; Franco, B. \& Kutsche, K. (2006). Mutations of the mitochondrial holocytochrome c-type synthase in X-linked dominant microphthalmia with linear skin defects syndrome. Am J Hum Genet, Vol.79, No.5, (Nov), pp. 878-89

Witters, I.; Legius, E.; Moerman, P.; Deprest, J.; Van Schoubroeck, D.; Timmerman, D.; Van Assche, F.A. \& Fryns, J.P. (2001). Associated malformations and chromosomal anomalies in 42 cases of prenatally diagnosed diaphragmatic hernia. Am J Med Genet, Vol.103, No.4, (Nov 1), pp. 278-82

Wolff, G. (1980). Familial congenital diaphragmatic defect: review and conclusions. Hum Genet, Vol.54, No.1, pp. 1-5

Zalis, E.G. \& Roberts, D.C. (1967). Ehlers-Danlos syndrome with a hypoplastic kidney, bladder diverticulum, and diaphragmatic hernia. Arch Dermatol, Vol.96, No.5, (Nov), pp. 540-4

Zelante, L. \& Ruscitto, M.M. (2003). Fusion of vertebrae, diaphragmatic hernia and unusual facies in a girl: a possible further case of Mathieu syndrome. Clin Dysmorphol, Vol.12, No.3, (Jul), pp. 207-8 
(C) 2012 The Author(s). Licensee IntechOpen. This is an open access article distributed under the terms of the Creative Commons Attribution 3.0 License, which permits unrestricted use, distribution, and reproduction in any medium, provided the original work is properly cited. 